\title{
The Economic Irrationality of the Patent Misuse Doctrine
}

\author{
Mark A. Lemley $\uparrow$
}

This Comment evaluates the economic effects of the patent misuse doctrine. The patent misuse doctrine is an equitable remedy analogous to the "unclean hands" doctrine in tort law. It bars infringement suits by patentees who have "misused" their patent grant, either by using the patent to violate the antitrust laws or by extending their patent monopoly in some other way. The author first describes the nature and scope of antitrust protection in the patent area, and contrasts the antitrust laws with the patent misuse doctrine. Next, the author argues that the patent misuse doctrine is irrational from an economic standpoint for three reasons: the level of sanction is unrelated to the injury caused; the sanction duplicates antitrust remedies, leading to excessive recoveries; and the sanction is awarded as $a$ windfall to the patent infringer even if that party was not injured by the misuse. These effects combine to make the patent misuse doctrine indefensible from the standpoint either of proportionality or of deterrence. Finally, the author reviews recent legislative efforts to reform the patent misuse doctrine and argues that they are misguided because they fail to deal with the fundamental problems described herein. The author concludes that the patent misuse doctrine ought to be abolished, and that the antitrust laws can serve the same purposes that the patent misuse doctrine was designed to serve.

\section{I}

\section{INTRODUCTION}

George Priest has described the economic analysis of the patent system as "one of the least productive lines of inquiry in all of economic thought." 1 In spite of abundant scholarship on the patent-antitrust intersection from some of the nation's greatest legal scholars, ${ }^{2}$ Priest

$\dagger$ B.A. 1988, Stanford University; J.D. candidate 1991, Boalt Hall School of Law, University of California, Berkeley. I wish to thank Professor Thomas M. Jorde for his many helpful suggestions on this Comment, Jan Bernian for putting up with ne while I wrote it, and Jim "Slash-and-Burn" Bayles for superb (if often painful) editorial assistance.

1. Priest, What Economists Can Tell Lawyers About Intellectual Property: Comment on Cheung, 8 RES. L. \& ECON. 19 (1986). Priest's answer to the question implied in his title is "very little." Id. at 21.

2. See, e.g., W. Bowman, Patent and Antrtrust Law: A Legal and Economic Appraisal (1973); Kaplow, The Patent-Antitrust Intersection: A Reappraisal, 97 HaRv. L. REv. 
concludes that "economists know almost nothing about the effect on social welfare of the patent system." 3

Virtually all the scholarship on the economic analysis of the patent system has focused on measuring optimal patent life, ${ }^{4}$ patent reward, ${ }^{5}$ or patent scope ${ }^{6}$ in an attempt to evaluate the benefits and costs of the patent systein and calculate exactly what that systein should protect and for how long.

This Comment will not resolve the problein of optimal patent life. Indeed, it does not attempt to do so. Instead, I take as given the existence of a societal presumption in favor of the patent system, and focus on the two methods by which the innovation system enforces coinpetition policy: antitrust law and the patent imsuse doctrine. Although this Comment recognizes an inherent conflict between the goals of the patent laws and the antitrust laws, ${ }^{7}$ I do not explore the optimial division of ground between the two. Thus, for purposes of this Comment, I will assume that the current law has codified both the scope and duration of patent grants efficiently. ${ }^{8}$

This Comment will argue that the patent misuse doctrine is indefensible froin an economic standpoint for several reasons. First, the sanction miposed bears no relation to the mjury caused. ${ }^{9}$ Second, the sanction duplicates antitrust remedies in many cases, leading to an excessive level of deterrence. ${ }^{10}$ Third, the doctrine often pays the sanction as a windfall to an unrelated third party, thereby encouraging infringement while failing to coinpensate those actually injured. ${ }^{11}$ These economic probleins lead one seriously to question the contimued vitality of the patent misuse doctrine as a whole.

Part II summarizes the enforcenent of the antitrust laws in cases

1813 (1984); Kitch, The Nature and Function of the Patent System, 20 J.L. \& EcoN. 265 (1977). These are the best-known of a flood of articles on the subject.

3. Priest, supra note 1 , at 21 .

4. See, e.g., Kaplow, supra note 2, at 1823-29 (attempting to derive the optimal patent life).

5. See, e.g., Kitch, supra note 2, at $282-83$ (discussing how reward theory has influenced the courts' view of the patent system).

6. Merges \& Nelson, On the Complex Economics of Patent Scope, 90 ColuM. L. Rev. 839, $842-43$ (1990).

7. Many commentators behieve that this conflict arises because the patent laws grant monopolies, whereas the antitrust laws are designed to prevent monopolies. See, e.g., Calkins, Patent Law: The Impact of the 1988 Patent Misuse Reform Act and Noerr-Pennington Doctrine on Misuse Defenses and Antitrust Counterclaims, 38 Drake L. REv. 175, 176 n.1 (1989). This description, lowever, oversimplifies the relationship. As discussed in Section IV(C), infra, the grant of a patent extends only to a particular product. Such a product is rarely coextensive with an entire product market as the term is used in antitrust analysis.

8. Indeed, the conclusions drawn in Parts IV and VI, infra, are more general, and apply regardless of the optimal scope or duration of a patent.

9. See infra notes 106-14 and accompanying text.

10. See infra notes $115-22$ and accompanying text.

11. See infra notes $124-27$ and accompanying text. 
involving patents, suggesting that those laws inay not extend far enough to deter anticoinpetitive conduct beyond the scope of the patent adequately. ${ }^{12}$ Part III describes the development and scope of the patent misuse doctrine, as well as the remedies for patent misuse. Part IV describes the economic irrationality of the patent misuse doctrine. Part $\mathrm{V}$ evaluates several recent legislative efforts to reforn the patent misuse doctrine. Fimally, Part VI considers whether there is any value to maintaining a distinct patent misuse doctrine in light of the doctrine's economic probleins.

II

\section{antitrust Enforcement in Patent Cases}

\section{A. Limits on Antitrust Enforcement in Patent Cases}

The antitrust laws do not distinguish between companies with patents and companies without thein. ${ }^{13}$ Thus, it is theoretically possible to enforce the antitrust laws againist all coinpaines, including those holding patents on their products. But this has never been the rule. Instead, courts have created exceptions to the antitrust laws for patentees. These exceptions vary depending on the type of anticompetitive conduct alleged. This Section will evaluate each of the four main categories of antitrust enforcement-1nonopolization, horizontal restraints, vertical restraints, and mergers-to illustrate how courts have failed to enforce the antitrust laws against patentees. ${ }^{14}$

\section{Monopolization}

Patents that lead to monopohes in a product inarket do not themselves violate the antitrust laws. ${ }^{15}$ Indeed, the Sherman Act itself prohibits only monopolization, not monopoly. ${ }^{16}$ Thus, the antitrust laws will

12. The extent to which the reticence of courts to enforce the antitrust laws may have been caused or exacerbated by the existence of the patent misuse doctrine itself is beyond the scope of this Comment. Even if antitrust underenforcement did "make up for" the overdeterrence problems discussed in Section IV(B), infra, it would do so in a haphazard fashion unlikely to optimize total deterrence.

13. See Clayton Act, 15 U.S.C. $\S 12$ et seq. (1988); Sherman Act, 15 U.S.C. $\S 1$ et seq. (1988).

14. Although the antitrust laws theinselves are not organized in this fashion, Professors Fox and Sullivan use this structure in their antitrust casebook. E. Fox \& L. SulLIVAN, CASES AND MATERIALS ON ANTTrRUST LAW (1989). I have adopted it here to assist in organization.

15. See Kaplow, supra note 2, at 1817 (Although the patent statute was not intended to bestow carte blanche upon each patentee for all its endeavors, "the very purpose of a patent grant is to reward the patentee by limiting competition, in full recognition that inonopolistic evils are the price society will pay."). Indeed, by the nature of the patent systein itself, a patentee receives a "monopoly" in the product he invents. Although this is not the equivalent of a inonopoly im an entire product market, see infra Section IV(C), patents can create antitrust inonopolies in two cases: (1) where a patentee creates the first product in a new market; and (2) where a patented product is such an improvement that it dominates an existing inarket.

16. 15 U.S.C. $\$ 2$ (1988); see also Uinited States v. Aluminum Co. of Am., 148 F.2d 416, 429 
not prevent a patentee from obtaining a patent solely because obtaining that patent would give him a monopoly. ${ }^{17}$ This follows from the broader rule that "the acquisition or maintenance of monopoly power as a result of a superior product does not violate the Sherman Act."18

A somewhat more difficult question arises, however, when a patentee is not granted a de facto monopoly, but rather uses the advantage of his patent to take over a product market. ${ }^{19}$ As noted above, patent laws clearly protect the competitive advantage granted by the patent itself. Recently, a number of lower courts, im a series of cases involvmg IBM, have concluded that the protection of the patent laws should extend to all unilateral conduct ${ }^{20}$ by the patentee to maintain his monopoly. ${ }^{21}$

In Transamerica Computer Co. v. IBM Corp., ${ }^{22}$ the district court (and later the Nimth Circuit) rejected Transainerica's clain that IBM violated the antitrust laws by changing its computer interfaces so that its competitors could not market compatible systems effectively. Even though the court found that IBM's "predominant imtent" was to prevent competition, ${ }^{23}$ the district court rejected the monopolization clains on the grounds that there were legitimate technological reasons for IBM's conduct. $^{24}$

Many recent decisions in the circuit courts have allowed virtually , any anticompetitive conduct if it has a colorable technological justification. ${ }^{25}$ This lenience towards dominant firms in technology-driven mdustries contrasts with the general rule against anticonıpetitive conduct designed to maintain a dominant market position. ${ }^{26}$

(2d Cir. 1945) ("It does not follow because 'Alcoa' had such a monopoly, that it 'monopolized' the ingot market....").

17. Such a situation typically would occur in the first of the two cases discussed at supra note 15 , where a patent creates a new inarket.

18. Transamerica Computer Co. v. IBM Corp., 481 F. Supp. 965,1003 (N.D. Cal. 1979), aff'd, 698 F.2d 1377 (9th Cir.), cert. denied, 464 U.S. 955 (1983).

19. As discussed above, an improvement leading to a competitive advantage in an existing market is one way a patent can create an antitrust monopoly. See supra note 15. The antitrust laws may apply with more force here than where the patent creates a new market. See Kaplow, supra note 2, at 1817 (patentee is not free to do "anything else it wishes solely on ... account [of having a patent]").

20. Multilateral action is considered in Sections $\mathrm{I}(\mathrm{A})(2)-(4)$, infra.

21. See California Computer Prods., Inc. v. IBM Corp., 613 F.2d 727, 744 (9th Cir. 1979) (IBM could change interfaces to deny competitors access to its mainframe); Transamerica, 698 F.2d at $1382-83$ (same).

22. 481 F. Supp. 965 (N.D. Cal. 1979), aff'd, 698 F.2d 1377 (9th Cir.), cert. denied, 464 U.S. 955 (1983).

23. Id. at 1005 .

24. Id. at 1005-06.

25. In addition to the cases cited supra notes 21-24, see Memorex Corp. v. IBM Corp., 636 F.2d 1188 (9th Cir. 1980) (per curiam), cert. denied, 452 U.S. 972 (1981).

26. See, e.g., United States v. Umited Shoe Mach. Corp., 110 F. Supp. 295, 344-45 (D. Mass. 1953) (outlawing conduct by a monopolist that made entry inore difficult), aff'd per curiam, 347 U.S. 521 (1954). 
Fraudulently obtaining a patent, as opposed to merely using a legitimately acquired patent, may constitute monopolization im violation of section 2 of the Sherman Act. In Walker Process Equipment, Inc. v. Food Machinery \& Chemical Corp. ${ }^{27}$ the Supreme Court held that intentional (but not technical) fraud can constitute anticompetitive conduct forming the basis for a charge of monopolization or attempted monopolization. ${ }^{28}$ Thus, good faith acquisition of a patent would seem to be a complete defense to an antitrust action arising from "fraud on the patent office."29

A patent fraud antitrust action atteinpts to demonstrate that the acquisition rather than the maintenance of monopoly power is illegal: that is, that the patent itself was improper and was therefore an "improper means" to acquire monopoly power. Where the patent is lawful, antitrust courts have been reluctant to condemn anticompetitive conduct that maintains the patent-assisted monopoly. ${ }^{30}$

\section{Horizontal Restraints}

Patentees may also use their patents to enforce cooperation or cartelization in an mdustry. This may be done unilaterally, through licensing agreements based on a single patent, or cooperatively, througl what is known as patent pooling. Althougl the Supreme Court has dealt with horizontal patent-based restraints on several occasions, the Court lias failed to articulate a clear standard for judging such restraints.

The leading case in this field (although its continuing validity is doubtful ${ }^{31}$ ) is United States v. General Electric Co. ${ }^{32}$ In General Electric, a patent holder licensed its product to a competitor, subject to the condition that the patent holder could set the competitor's prices. The Court sustained the licensing restriction (whicli anounted to a cartel setting horizontal prices), finding it "reasonably withni the reward" of the patent. $^{33}$ A straightforward reading of General Electric suggests that patentees are immune from antitrust liability if they form a cartel based on

27. 382 U.S. 172 (1965).

28. Id. at 174-78; see also Bendix Corp. v. Balax, Inc., 421 F.2d 809, 819 (7th Cir.) (fraud but not good faith mistake will constitute misuse), cert. denied, 399 U.S. 911 (1970). In addition to showing fraud, the plaintiff must also show that the defendant has market power. Walker Process, 382 U.S. at $177-78$.

29. Judge Posner suggests that a successful antitrust claim for patent fraud must meet two additional requirements. First, the invention must not be patentable at all (that is, the fraud must go to patentability, and not inerely to defendant's rights to the patent). Second, the patent grant must have had some presumption of validity in the market (and thus soine impact on the market). Brunswick Corp. v. Riegel Textile Corp., 752 F.2d 261, 265-66 (7th Cir. 1984), cert. denied, 472 U.S. 1018 (1985). The Supreme Court has neither considered nor adopted Judge Posner's test.

30. See, e.g., Brunswick, 752 F.2d at 265; see also cases cited supra notes 21 \& 25.

31. See infra notes $35-41$ and accoinpanying text.

32. 272 U.S. 476 (1926).

33. Id. at $489-91$. 
licenses of the patented product. ${ }^{34}$

A number of lower courts proceeded almost immediately to limit the scope of General Electric, ${ }^{35}$ and the decision's sliaky foundation was exposed when the Supreme Court, considering a different issue, repudiated the rationale underlying General Electric in United States v. Masonite Corp. ${ }^{36}$ Fimally, in 1948, the Supreme Court took a large step towards applying the antitrust laws to patent-based cartels. In United States $v$. Line Material Co., ${ }^{37}$ the Court condemned as unlawful per se a crosslicensing agreement in which the patentees fixed prices for all their products. In finding the agreement unlawful, the Court limited General Electric to unilateral licensing (presumably because it looks less like a conspiracy). ${ }^{38}$ Four Justices concurred, expressing the view that General Electric slould be overruled. ${ }^{39}$ On the same day, the Court found that a series of individual license agreements between the same parties amounted to a conspiracy to cross-license and set prices, and was therefore illegal under the newly established Line Material rule. ${ }^{40}$

As a result of these cases, antitrust law is now generally applicable to horizontal restraints of trade stemming from patents. But General Electric has never been fornally overruled, and at least one case seems to suggest tliat patent pooling to settle an infringement dispute would be judged under the rule of reason, rather than the per se rule traditionally

34. The reader might immediately object that General Electric's approval of cartels is limited to those cases in which the patent happens to be broad enough to control a product market. See supra note 15. For two reasons, this is not necessarily the case. First, major firms in a technologydriven industry may individually hold different patents, and the firms could pool these patents in a cartel without fear of antitrust liability. Second, the prospect of such a "safe" cartel might induce firms that otherwise would compete with the patentee to produce the patented product under license instead.

35. See, e.g., Cummer-Graham Co. v. Straight Side Basket Corp., 142 F.2d 646, 647-48 (5th Cir.) (licensee could not coinpel licensor to enforce its own patent-based price-fixing agreements), cert. denied, 323 U.S. 726 (1944); Barber-Colman Co. v. National Tool Co., 136 F.2d 339, 343-44 (6th Cir. 1943) (General Electric did not permit price fixing of unpatented products produced by patented machines); United States v. Vehicular Parking, Ltd., 54 F. Supp. 828, 841 (D. Del. 1944) (finding that restrictive licenses by patent holding company were illegal and ordering compulsory licensing).

36. 316 U.S. 265 (1942). General Electric had reasoned that since a patentee could refuse to license its product entirely, that patentee could impose a wide range of conditions on licenses it cliose to grant. General Electric, 272 U.S. at 490 . Masonite held that leveraging a patent inonopoly (that is, using the patent monopoly to gain monopoly control over another product market through (ying) violated the antitrust laws, rejecting the "conditions" argument put forward in General Electric: "[I]t will not do to say that, since the patentee has the power to refuse a license, he has the lesser power to license on his own conditions." Masonite, 316 U.S. at 277. For a discussion of tying, see infra notes 152-57 and accompanying text.

37. 333 U.S. 287 (1948).

38. Id. at 310-12.

39. Id. at 315-16 (Douglas, J., concurring).

40. United States v. United States Gypsum Co., 333 U.S. 364, 389-91 (1948); see also United States v. New Wrinkle, Inc., 342 U.S. 371, 379-80 (1952) (reaffirming United States Gypsum on similar facts). 
applied to horizontal conspiracies. ${ }^{41}$

\section{Vertical Restraints}

Traditional antitrust analysis of vertical restraints focuses on two main concerns: 1) whether the restraints control prices; and 2) whether the restraints are unilaterally imposed or are the product of an agreement. Only agreements that directly restrict price are illegal per se. ${ }^{42}$ These rules appear to apply with equal force in patent cases. Thus, a patent will not protect a defendant engaging in resale price maintenance. ${ }^{43}$

Vertically leveraging a patent-using the patent monopoly at one level, such as production, to take over another level, sucl as distribution-presents a tougher issue for the courts. ${ }^{44}$ The leading case on vertical leveraging is Berkey Photo, Inc. v. Eastman Kodak Co. ${ }^{45}$

In Berkey Photo, the Second Circuit approved vertical leveraging in the innovation context, holding that Kodak could use its market share in certain parts of the film and cainera industry to take over otler parts of that industry. ${ }^{46}$ Berkey claimed imjury because Kodak could develop and introduce new cannera formats, while its competitors could not (since only Kodak made the film for any cainera format). Berkey therefore deinanded advance disclosure of Kodak's future cainera technology. The court rejected this request, noting that "[i]f a firm that has engaged in the risks and expenses of research and development were required in all circumstances to share with its rivals the benefits of those endeavors, this incentive [to innovate] would very likely be vitiated."47 The court implied that to hold for Berkey would essentially establish a compulsory

41. See Standard Oil Co. (Indiana) v. United States, 283 U.S. 163, 170-71 (1931) (viewing patent pooling as monopolization rather than cartelization, and discussing potential efficiencies); see also E. Fox \& L. SullivaN, supra note 14, at 353-54 ("The decision in Standard Oil (Indiana) can be read as implying that settlement of a patent dispute by aggregating several competing patents into a pool is reasonable, and therefore lawful ....").

42. Compare Dr. Miles Med. Co. v. Park \& Sons, 220 U.S. 373, 408 (1911) (agreement to fix resale prices is illegal per se) with Business Elec. Corp. v. Sharp Elec. Corp., 485 U.S. 717, 726-27 (1988) (agreenient to terminate discounter judged under the rule of reason, simce it is a nonprice restraint) and Continental T.V., Inc. v. GTE Sylvania, Inc., 433 U.S. 36, 57-59 (1977) (nonprice restraints judged under the rule of reason) and with United States v. Colgate \& Co., 250 U.S. 300, 306-08 (1919) (unilateral price restraints are legal).

43. Ethyl Gasoline Corp. v. United States, 309 U.S. 436, 457-58 (1940) ("[A]fter the [first] sale neither appellant nor the refiners may [any] longer rely on the patents to exercise any control over the price at which the fuel may be resold.").

44. The related issue of horizontal leveraging, or tying, is treated along with patent misuse in Seetion III(B), infra, since most such cases arise in that context. Horizontal leveraging of a patent may also violate the antitrust laws. See United States v. Univis Lens Co., 316 U.S. 241, 250-51 (1942).

45. 603 F.2d 263 (2nd Cir. 1979), cert. denied, 444 U.S. 1093 (1980).

46. Id. at $282-83$.

47. Id. at 281. 
licensing sclieme against Kodak, soinething the court was unwilling to do. ${ }^{48}$ Thus, the Berkey court appears to have established a leveraging standard in innovation cases tliat is more lenient than the standard in other cases. ${ }^{49}$

\section{Mergers and Acquisitions}

Acquiring or extending a patent monopoly by inerging with a patentee or by purchasing patents presents a problein of more recent vintage. Section 7 of the Clayton Act now prohibits asset acquisitions that harm competition, ${ }^{50}$ and courts have generally been willing to include intangible property riglits such as copyrights and tradeinarks in their definitions of "assets." 51 Thus, if a patent is an asset, as seenis likely, then patent acquisitions may violate the antitrust laws. Indeed, several lower courts liave come to this very conclusion. ${ }^{52}$

On the otlier liand, aggregation of patents developed through a corporation's own research does not constitute an antitrust violation. ${ }^{33}$ Moreover, the acquisition of patents is not itself illegal unless it restricts competition or tends to create a monopoly. ${ }^{54}$ In short, courts treat the acquisition of inarket power througli purchase of patents in the saine way infra.

48. Id. at 284-85. Compulsory licensing as an antitrust remedy is discussed in Section II(B),

49. Compare Jefferson Parish Hosp. Dist. v. Hyde, 466 U.S. 2, 13-14 (1984) (tying arrangeinents are "unreasonable per se" if the tying party has inarket power) with Berkey Photo, 603 F.2d at 270 (vertical leveraging analyzed under rule of reason despite Kodak's market power). $C f$. Kramer, The Supreme Court and Tying Arrangements: Antitrust As History, 69 MinN. L. Rev. 1013, 1023 (1985) (concluding on the basis of legislative history that section 3 of the Clnyton Act, 15 U.S.C. $§ 14$ (1988), was designed in part to outlaw tying arrangements).

50. Clayton Act $\S 7$ (codified at 15 U.S.C. $\S 18$ (1988)). This provision was added by the Celler-Kefauver Act of 1950, Pub. L. No. 81-899, 64 Stat. 1125 (1950).

51. See, e.g., United States v. Lever Bros., 216 F. Supp. 887, 889 (S.D.N.Y. 1963) (tradenark is an asset within the meaning of section 7); United States v. Columbia Pictures Corp., 189 F. Supp. 153, 182-83 (S.D.N.Y. 1960) (copyright is an asset under section 7 .

52. See, e.g., SCM Corp. v. Xerox Corp., 645 F.2d 1195, 1205 (2d Cir. 1981), cert. denied, 455 U.S. 1016 (1982); Kobe, Inc. v. Dempsey Pump Co., 198 F.2d 416, $422-24$ (10th Cir.), cert. denied, 344 U.S. 837 (1952); United States v. Besser Mfg. Co., 96 F. Supp. 304, $310-11$ (E.D. Mich. 1951), aff'd, 343 U.S. 444 (1952). For similar reasons, of course, a merger between two companies that violates section 7 is not immune from antitrust liability simply becausc the firms own patents. To this extent, at least, the antitrust laws apply to patentees.

53. Indeed, such imilateral action does not raise a Clayton Act section 7 claim at all, since that section prevents only external expansion, not internal growth. Section 7 provides only that "[n]o person ... shall acquire ... the whole or any part of the stock or other share capital ... of another person" where it will restrain competition. 15 U.S.C. $\S 18$ (1988). Growth by means other than acquisition does not fall within section 7.

54. Automatic Radio Mfg. Co. v. Hazeltine Research, Inc., 339 U.S. 827, $833-34$ (1950) (acquisition not illegal where it does not extend market power), overruled on other grounds by Lear, Inc. v. Adkins, 395 U.S. 653, 664 (1969); cf. Transparent-Wrap Macli. Corp. v. Stokes \& Simith Co., 329 U.S. 637 (1947) (acquisition of patent is illegal where it restricts competition). 
as any other merger or acquisition within an industry. ${ }^{55}$

\section{Conclusions}

Antitrust law is somewhat confused in its application to patent cases. Furthermore, there is a dearth of Supreme Court patent cases outside the horizontal restraints area. Although antitrust rules in patent cases generally parallel those in nonpatent cases, there are some significant departures, as noted im this Section. The remainder of this Comment will discuss these departures and suggest ways to reform antitrust and misuse coverage of patents.

\section{B. Antitrust Remedies in Patent Cases}

Antitrust remedies in general are botli broad and well-established. Appropriate remedies imclude treble damages, mjunctions against anticompetitive conduct, and, in certain cases, divestiture of illegal acquisitions. $^{56}$ In general, antitrust remedies are the same in both patent and nonpatent cases. There are, however, two remedies issues that courts approach somewliat differently in patent cases.

First, courts generally have been reluctant to use divestiture remedies im patent cases, in part because of practical problems and in part because such remedies would destroy the rewards of the patent laws. United States v. United Shoe Machine Co. ${ }^{57}$ is an exainple of the former. In United Shoe, Judge Wyzanski denied structural rehef because of implementation problems, even though. United Shoe was a monopohist with a history of anticompetitive conduct and prior antitrust violations. ${ }^{58}$ Furthermore, divestiture Inust be carefully limited in inonopolization cases involving patents if the court is to optimize patent protection. The objective of divestiture should be to deprive a defendant of only the market share that resulted froin anticoinpetitive conduct, while allowing the defendant to retain any monopoly power that resulted from the legal patent grant. 59

The second, and more controversial, remedies issue im patent cases is

55. See W. Bowman, supra note 2, at 200 ("The problem of patent accumulation .... is conceptually imdistinguishable from the merger problem under antitrust law.").

56. A detailed description of the remedies generally available in antitrust cases is beyond the scope of this Comment. For a brief general discussion, see P. AREedA \& L. KaPLOW, ANTITRUST ANAIYSIS 184-85 (1987).

57. 110 F. Supp. 295 (D. Mass. 1953), aff'd per curiam, 347 U.S. 521 (1954).

58. Id. at 346-48. The remedies problem arose because United Shoe could not be dissolved geographically sincc its three plants were integrated vertically, and dividing the firm into three different vertical firms would have left none of the parts viable. Id.

59. The reasoning behind such limited divestiture is obvious. If the point of the patent grant is to create a legal monopoly, it makes no seuse to take that monopoly away. Only the additional market share ought to be affected. See Kaplow, supra note 2, at 1869-70 (eudorsing this view).

Such a problem does not arise in acquisitions cases under section 7 of the Clayton Act, since 
the wisdom of ordering compulsory hicensing of patents. As its name implies, a compulsory licensing remedy requires the patentee to license the production and sale of its patented product to all comers (presumably at a "reasonable rate" set by the court ${ }^{60}$ ). This approacli has all the difficulties inherent in government regulation of the market, ${ }^{61}$ and inost commentators have opposed it. ${ }^{62}$ Nonetlieless, many courts have ordered compulsory hicensing as an antitrust remedy. ${ }^{63}$ In Part VI, this Comment will discuss compulsory licensing as an antitrust reinedy, ${ }^{64}$ concluding that such a remedy should be used sparingly (even apart from its administrative problems), because it is largely inconsistent with the nature of the patent laws.

III

\section{The Patent Misuse Doctrine}

\section{A. The Nature and Development of the Doctrine}

The patent misuse doctrine originally developed as a cominon law equitable affirmative defense to an infringement claim, similar to the

divestiture can simply restore the status quo ante, returning to each party the patents it owned before the merger.

60. If the court does not set a reasonable royalty but lets the patentee set it instead, the compulsory licensing seheme will be ineffective, since the patentee can simply set an arbitrarily high royalty rate (which will have the same effect as granting no lieense at all).

If, on the other hand, the court orders royalty-free compulsory hicensing, see, e.g., United States v. General Elec. Co., 115 F. Supp. 835, 844-45 (D.N.J. 1952), it in essence takes all the patent benefit away from the patentee. Courts in general have not favored royalty-free licensing. See HartfordEmpire Co. v. Umited States, 323 U.S. 386, 414-17 (1945) (rejeeting compulsory hicensing remedy except in extreme cases); see also P. AREedA \& L. KAPLow, supra note 56, at 184-85 (citing cases demonstrating judicial reluctance to use coinpulsory hicensing).

61. Indeed, since the court will attempt to set a market rate for a product and require its salc at that rate, compulsory licensing is virtually indistinguishable from, for example, the regulation of an electric utility. Such regulation by the courts following an antitrust violation not only raises problems relating to the determination of an appropriate price, but also would create an ongoing administrative mightmare for the judicial branch.

62. See, e.g., W. Bowman, supra note 2, at 243-49; Scherer, The Economic Effects of Compulsory Patent Licensing, N.Y.U. GRAD. SCH. Bus. ADMIN. MONOGRAPH SERIES IN FIN. \& ECON. (1977).

63. See, e.g., United States v. Glaxo Group, Ltd., 410 U.S. 52, $60-65$ (1973); United States v. National Lead Co., 332 U.S. 319, 328-35 (1947); Hartford-Empire Co. v. United States, 323 U.S. 386, 419 (1945); see also F. Scherer, Industrial Market STructure AND Economic PERFoRMANCE 456 (1980) ("[C]ompulsory licensing las been specified as a remedy in more than 125 antitrust cases . . . "); $c f$. United States v. Umited Slıoe Mach. Corp., 110 F. Supp. 295, 348-50 (D. Mass. 1953), aff'd per curiam, 347 U.S. 521 (1954) (requiring that lieensing be nondiscriminatory if defendant chooses to liceuse); United States v. General Elec. Co., 82 F. Supp. 753, 900 (D.N.J. 1949) (refusal to license is an antitrust violation when the patentee is a dominant firm). The Supreme Court has rejected royalty-free licensing, however. See Hartford-Empire, 323 U.S. at 414-15.

64. One could theoretically require compalsory hicensing of all patents, a proposal that would require a thorough revision of our patent system. Such an idea can be ignored for purposes of this Comment. 
traditional "unclean hands" doctrine in tort law. ${ }^{65}$ Under the doctrine, defendants in an infringeinent or contributory infringement action can claim that the patentee plaintiff has "misused" its patent grant. ${ }^{66}$ If the defense is successful, courts will refuse to grant injunctive or darnage rehief to the patentee for infringement ${ }^{67}$ until such time as the patentee has stopped its misuse and the effects of that misuse have dissipated. ${ }^{68}$

Although the historical developinent of the patent misuse doctrine is well catalogued, ${ }^{69}$ I will briefly describe the salient features here. The Supreme Court first recognized a patent misuse defense in 1917 , in Motion Picture Patents Co. v. Universal Film Manufacturing Co. ${ }^{70}$ In Motion Picture, the Court held that a tying arrangement in which the patentee required exhibitors to show only its movies on its patented projector was a misuse of the patent. In a number of subsequent cases, the Court invalidated other tying arrangements. ${ }^{71}$ In Mercoid Corp. v. MidContinent Investment Co. (Mercoid I), ${ }^{72}$ the Court extended Motion Picture's tying prohibition to a case in which the patentee "tied" a nonstaple product to the patented product. ${ }^{73}$ In 1952, Congress passed legislation

65. See infra note 107 .

66. Two cases have created a "copyright misuse" doctrine similar to the patent misuse doctrine. Lasercomb Am., Inc. v. Reynolds, 911 F.2d 970, 973 (4th Cir. 1990); M. Witmark \& Sous v. Jensen, 80 F. Supp. 843 (D. Minn. 1948), appeal dismissed, 177 F.2d 515 (8th Cir. 1949). The United States Supreme Court has never ruled on the validity of the copyright misuse defense. Lasercomb, 911 F.2d at 976 . While copyrights and patents are very different, the problems with the patent misuse doctrine discussed in Part IV, infra, may apply in the copyright context as well.

67. See, e.g., Morton Salt Co. v. G.S. Suppiger Co., 314 U.S. 488, 493-94 (1942) (denying equitable relief); accord P. AREEDA \& L. KAPLOW, supra note 56, at 182 ("The courts will neither enjoin an infringement nor award damages for it when the patent has been "misused." "); see also D. ChISUM, 3 PATENTS $\S 19.04$, at 19-91 (1990) ("If such misuse is found, the courts will withhold any remedy for infringement.") (emphasis added).

68. B.B. Chem. Co. v. Ellis, 314 U.S. 495, 498 (1942); P. AREedA \& L. KAPLow, supra note 56 , at $182-83$; D. ChISUM, supra note $67, \S 19.04$, at 19.91 .

69. The classic treatment is D. CHISUM, supra note $67, \S 19.04$, at 19-91 to 19-158. See also Calkins, supra note 7, at 178-92; Harris, A Centrist Program on Competition Derived From the Patent-Antitrust Experience, 47 GEO. WASH. L. REv. 1, 18-69 (1978).

70. 243 U.S. 502 (1917). Motion Picture overruled Henry v. A.B. Dick Co., 224 U.S. 1 (1912), then only five years old, which had held that leveraging of a patent was within the patent monopoly. Henry, 224 U.S. at 34-35. Motion Picture also impliedly abandoned some earlier decisions rejecting a patent misuse defense. See, e.g., Strait v. National Harrow Co., 51 F. 819, 820-21 (C.C.N.D.N.Y. 1892) (basing defense on common law equitable theories).

71. See Ellis, 314 U.S. at 495 (tying a shoe reinforcing patent to unpatented shoe reinforcing materials); Morton Salt, 314 U.S. at 488 (tying salt deposit machine and salt tablets); Leitch Mfg. Co. v. Barber Co., 302 U.S. 458 (1938) (tying concrete curing patent to sale of unpatented curing material); Carbice Corp. v. American Patents Dev. Corp., 283 U.S. 27 (1931) (tying dry ice combination patent to sale of dry ice). All these cases except Morton Salt found patent misuse without considering whether the patentee's conduct amounted to an antitrust violation.

72. 320 U.S. 661 (1944).

73. Id. at 664-65. The Court reaffirmed its ban on the tying of nonstaple products in Transparent-Wrap Machine Corp. v. Stokes \& Smith Co., 329 U.S. 637, 640-41 (1947).

A nonstaple product is "one that has no commercial use except in comrection with respondent's patented invention." Dawson Chem. Co. v. Rohın \& Haas Co., 448 U.S. 176, 184 
intended to reverse Mercoid $I$ and limit the patent misuse doctrine to the tying of staple products. ${ }^{74}$ Recent legislation further limits the application of patent misuse with regard to tying arrangeinents. ${ }^{75}$

The patent misuse doctrine has several unusual features. First, it is codified only inversely. That is, it is a common law doctrine that continues to exist alongside statutory patent law, but its parameters have been expressly limited by statute. ${ }^{76}$ This rather unusual legal development is well traced in Dawson Chemical Co. v. Rohm \& Haas Co. ${ }^{77}$

Second, the patent misuse doctrine is available only as an affirmative defense in infringement cases. Patentees cannot be sued for misuse or enjoined froin misusing their patents. ${ }^{78}$ This leads to two anomalous resnlts. Since patentees have no reason to sue noninfringing third parties for infringement, only patent infringers benefit from the doctrine. In addition, smce there is no requirement that the misuse have harmed the infringer using the defense, the patent misuse doctrine benefits any infringer whose patentee has committed misuse. ${ }^{79}$

(1980). Because any separate market for a nonstaple product necessarily will depend on the continued use of the patent by the patentee, the "market" is artificial in some basic sense. Restricting this artificial market through tying creates less of a market dislocation than would restricting an otherwise viable market. See R. POSNER, ANTITRUST LAW: AN ECONOMIC PERSPECTIVE 173 (1976) (questioning "why a firm with a monopoly of one product would want to monopolize complementary products as well") (emphasis in original).

74. See Dawson Chem. Co. v. Rohm \& Haas Co., 448 U.S. 176, 209 (1980) (intent of Congress in passing 35 U.S.C. $\$ 271$ (d)(1)-(3) (1988), was to reverse Mercoid $I$ ). While Professor Harris contended in 1978 that Mercoid I retained some vitality in spite of the passage of section 27l(d), Harris, supra note 69, at 23-24, the Supreme Court's 1980 opinion in Dawson Chemical appears firmly to reject that view.

75. See infra Section V(B) (discussing Patent Misuse Reform Act of 1988).

76. 35 U.S.C. $\$ 271$ (d)(1)-(3) (1988), first passed in 1952, Pub. L. No. 82-593, 66 Stat. 811, limited the reach of the patent misnse doctrine by stating that certain specified acts did not constitute patent misuse. Until 1988, that section provided only:

(d) No patent owner otherwise entitled to relief for infringement or contributory infringement of a patent shall be denied relief or deemed guilty of misuse or illegal extension of the patent right by reason of his having done one or more of the following: (1) derived revenue fronl acts which if perfonned by another without his consent wonld constitute contributory infringenient of the patent; (2) heensed or authorized another to perforn acts which if perforned without his consent wonld constitute contributory infringement of the patent; (3) sought to enforce his patent rights against infringement or contributory infringement.

The recent amendinents to section 271(d), adding (d)(4)-(5), Patent Misuse Reform Act of 1988, Pub. L. No. 100-703, 102 Stat. 467 [hereinafter PMRA], are discussed in Part V, infra.

77. 448 U.S. 176, 202-15 (1980).

78. Morton Salt Co. v. G.S. Suppiger Co., 314 U.S. 488, 492 (1942) (discussing "equitable discretion" rationale for doctrine). The rationale behind this limited grant of rehef is that the courts merely wish to avoid aiding a misuser, rather than affirmatively to sanction him. P. AREEDA \& $L$. KAPLOW, supra note 56, at 182.

79. See infra Section III(B). The effects of these anomalies on the economic rationality of the patent misuse doctrine as a whole are discussed in Part IV, infra. 


\section{B. The Scope of the Doctrine}

In general, the definition of patent misuse tracks the antitrust laws quite closely. That is, activities by patentees that constitute patent misuse are likely to constitute antitrust violations as well. ${ }^{80}$ But even though the Court in Motion Picture relied on the recently adopted Clayton Act as a guideline in creating tlie patent misuse doctrine, ${ }^{81}$ it mibued the new doctrine with an independent basis-the public policy underlying the patent laws. ${ }^{82}$ Thus, activities constituting patent misuse can (and often do) diverge froin those activities constituting antitrust violations. ${ }^{83}$

In practice, this divergence inakes patent misuse easier to prove than an antitrust violation for three reasons. First, an activity can constitute patent misuse without constituting an antitrust violation. ${ }^{84}$ Since the

80. See Ansul Co. v. Uniroyal Inc., 448 F.2d 872 (2d Cir. 1971); P. AREedA \& L. KAPLow, supra note 56, at 183; cf. USM Corp. v. SPS Technology, Inc., 694 F.2d 505, 512 (7th Cir. 1982) (misuse must be tested by antitrust principles), cert denied, 462 U.S. 1107 (1983).

81. Motion Picture Patents Co. v. Universal Film Mfg. Co., 243 U.S. 502, 517-18 (1917); see Calkins, supra note 7, at 180 .

82. Calkins, supra note 7, at 181. For a discussion of those policies, see infra notes 101-02 and accompanying text.

83. Calkins, supra note 7, at 187 n.38. Professor Calkins contends that ten types of recognized patent misuse defenses exist: resale price maintenance, tying arrangements, resale territorial restrictions, noncompetition agreements, package licensing (where it amounts to tying), restrictions extending beyond the tenn of the patent, nonmetered royalties, refusal to hicense, resale field-of-use limitations, and grant-back clauses. Id.

Many of these claims, if proven, would also constitute antitrust violations. See, e.g., United States Steel Corp. v. Fortner Enters., Inc., 429 U.S. 610, 611 (1977) (Fortner In) (tying arrangements); White Motor Co. v. United States, 372 U.S. 253, 255-56, $263-64$ (1963) (resale nonprice restrictions); United States v. Parke, Davis \& Co., 362 U.S. 29, 44 (1960) (resale price nuaintenance).

Others, lowever, such as nonmetered royalties, refusal to license, resale field-of-use limitations, and grant-back clauses, are not antitrust violations unless they aunount to tying arrangements with market power. See, e.g., Olyınpia Equip. Leasing Co. v. Western Umion Tel. Co., 797 F.2d 370, 37677 (7th Cir. 1986) (refusal to deal), cert. denied, 480 U.S. 934 (1987); Rothery Storage \& Van Co. v. Atlas Van Lines, Inc., 792 F.2d 210, 217-21 (D.C. Cir. 1986) (noncompetition agrecments), cert. denied, 479 U.S. 1033 (1987). Such conduct could, however, be part of a tying arrangement, which is an antitrust violation under certain conditions. Jefferson Parish Hosp. Dist. v. Hyde, 466 U.S. 2, 13-14 (1984); see, e.g., Transparent-Wrap Mach. Corp. v. Stokes \& Smith Co., 329 U.S. 637, 647-48 (1947) (grant-back clause may also be an antitrust violation im some circumstances).

In spite of these differences, Judge Posner has suggested that, at least outside of tying cases, "there is increasing convergence of patent-misuse analysis with standard antitrust analysis." USM Corp., 694 F.2d at 511.

84. See supra note 83. In addition to the examples noted there, a possible distinction between the scope of the antitrust and patent misuse doctrines could be seen (at least until recently) in the refusal to license a patent. At least one court has found that refusal to license constituted patent misuse. Leitch Mfg. Co. v. Barber Co., 302 U.S. 458, 463 (1938) (refusal to license sale of nonstaple products for use in patented method constitutes patent misuse, since it illegally extends the patent). But the PMRA, 35 U.S.C. \$271(d)(4) (1988), expressly states that "refus[al] to license or use" patent rights does not coustitute patent misuse. Id.

It is likely that refusal to license would not constitute an antitrust violation. See, e.g., Olympia Equipment, 797 F.2d at 376 (refusing to compel licensing); Berkey Photo, Inc. v. Eastman Kodak Co., 603 F.2d 263 (2d Cir. 1979) (same), cert. denied, 444 U.S. 1093 (1980). But see American 
patent misuse doctrine has a pohicy foundation separate from the antitrust laws, ${ }^{85}$ there is no theoretical bar to the creation of non-antitrust classes of patent misuse.

Second, patent misuse can often be proven without some key element of an antitrust case. This is particularly true in tying cases. Several categories of patent misuse, such as nonmetered royalties and resale fieldof-use limitations, do not constitute antitrust violations unless they amount to inonopolization or atteinpted monopolization of the tied product $^{86}$ by a defendant with market power. ${ }^{87}$ But proof of market power traditionally has not been necessary to prove patent misuse. ${ }^{88}$ More miportantly, a defendant need not show mjury to coinpetition to prove patent misuse, ${ }^{89}$ as is required to show an antitrust violation. ${ }^{90}$ As a result, courts have refused to find that proof of patent misuse necessarily proves an antitrust violation. ${ }^{91}$

Fimally, the antitrust standing requirement is completely absent from the patent misuse defense. An antitrust plaintiff (or a defendant asserting an antitrust counterclaim) must prove injury "of the type the antitrust laws were intended to prevent and that flows from that which makes the defendants' acts uulawful."92 By contrast, a defendant asserting patent misuse need not prove individual harm froin the misuse at

Photocopy Equip. Co. v. Rovico, Inc., 359 F.2d 745, 747 (7th Cir. 1966) (refusing to license except at "exorbitant and oppressive" royalties violates the antitrust larvs).

85. See supra note 82 and accompanying text.

86. Zemith Radio Corp. v. Hazeltine Research, Inc., 395 U.S. 100, 137-38 (1969) (nonmetered royalties constitute misuse only if patentee has market power); General Talking Pictures Corp. v. Western Elec. Co., 304 U.S. 175, 181, aff'd on reh'g, 305 U.S. 124 (1938).

87. Northern Pac. Ry. Co. v. United States, 356 U.S. 1, 6 (1958).

88. See Senza-Gel Corp. v. Seiffhart, 803 F.2d 661 (Fed. Cir. 1986). The PMRA now requires that defendants alleging patent misuse prove market power in tying cases. 35 U.S.C. $\$ 271$ (d)(5) (1988).

89. Noll v. O.M. Scott \& Sons Co., 467 F.2d 295, 301 (6th Cir. 1972), cert. denied, 411 U.S. 965 (1973); Berlenbach v. Anderson \& Thompson Ski Co., 329 F.2d 782, 784 (9tlı Cir.), cert. denied, 379 U.S. 830 (1964); Transitron Elec. Corp. v. Hughes Aircraft Co., 487 F. Supp. 885, 892.93 (D. Mass. 1980).

90. Atlantic Richfield Co. v. USA Petroleum Co., 110 S. Ct. 1884, 1893-95 (1990) (private party can bring antitrust action only if she alleges imjury to competition); $c f$. Brown Shoe, Inc. v. Umited States, 370 U.S. 294, 320 (1962) ("the legislative history [of the antitrust laws] illuminates Congressional concern with the protection of competition, not competitors") (emphasis in original).

91. See, e.g., Zenith Radio Corp. v. Hazeltine Researcl, Inc., 395 U.S. 100, 140 (1969); see also Laitram Corp. v. King Crab, Inc., 245 F. Supp. 1019, 1020 (D. Alaska 1965) ("doctrine of misuse of patents does not necessarily include a violation of the antitrust laws ..."; finding patent misuse but no antitrust violation); Waco Porter Corp. v. Tubular Structures Corp., 222 F. Supp. 332, 334-35 (S.D. Cal. 1963). Another reason not to accept patent misuse as an autornatic antitrust violation is that the market definition in patent misuse cases may be narrower than in antitrust cases. Senza-Gel, $803 \mathrm{~F} .2 \mathrm{~d}$ at $670-71 \mathrm{n} .14$. The effects of this dual system of protecting competition are discussed in Part IV, infra.

92. Cargill, Inc. v. Monfort of Colo., Inc., 479 U.S. 104, 109 (1986) (quoting Brunswick Corp. v. Pueblo Bowl-O-Mat, Inc., 429 U.S. 477, 489 (1977)). 
all. ${ }^{93}$ Instead, any defendant in an infringement action is protected from suit if she can prove that the plaintiff misused the patent, even if the defendant was unaffected by the misuse. ${ }^{94}$

\section{Patent Misuse Remedies}

If a patentee has misused his patent, the courts will neither enjoin an infringement of that patent nor award dainages to the patentee. Thus, the patent misuse doctrine is essentially a complete affirmative defense to charges of infringement. ${ }^{95}$ It is a doctrine of equity created by the courts im order to further the public interest. The doctrine applies to a misusing patentee until she ceases her misuse and the consequences of that misuse are "fully dissipated."

Although patent misuse remedies seem firmly estabhished, there have been some aberrations in the circuit courts. One appellate court suggested that the equivalent of compulsory hicensing might be an appropriate remedy for patent misuses that injure the public imterest. ${ }^{97}$ This suggestion did not gain widespread acceptance. Another court has suggested that infringers cannot benefit from the patent misuse doctrine unless they have had some connection to the misuse. ${ }^{98}$ Presumably, the connection would be that the infringers were $\mathrm{m}$ fact injured by the misuse. Requiring this connection would thus establish an injury standing requirement in patent misuse cases, albeit a weaker one than is currently

93. Morton Salt Co. v. G.S. Suppiger Co., 314 U.S. 488, 490 (1942); accord D. ChisuM, supra note 67, $\S 19.04$, at 19-158 ("[I]t has been clear at least since Morton Salt that the individual defendant raising a misuse defense need not show that he was personally harmed by the abusive practice.") (citations omitted).

94. See Transitron Elec. Corp. v. Hughes Aircraft Co., 487 F. Supp. 885, $892-93$ (D. Mass. 1980); Duplan Corp. v. Deering Milliken, Inc., 444 F. Supp. 648, 757-58 (D.S.C. 1977), aff'd in part and rev'd in part on other grounds, 594 F.2d 979 (4th Cir. 1979), cert. denied, 444 U.S. 1015 (1980). As Professors Areeda and Kaplow note, this fact inakes patent misuse relevant even if the patentee has violated the antitrust laws, since someone who could not bring an antitrust claim against a patentce because of the standing doctrine could nonetheless benefit from the patent misuse doctrine. P. AREEDA \& L. KAPLOW, supra note 56, at 183 n.41.

95. P. AREEDA \& L. KAPLOW, supra note 56, at 182.

96. B.B. Chem. Co. v. Ellis, 314 U.S. 495, 498 (1942); accord D. CHIsUM, supra note 67, $\S 19.04$, at $19-156$ to $19-158$.

97. Umited States v. General Elec. Co., 115 F. Supp. 835, 844 (D.N.J. 1953); cf. Vitamin Technologists, Inc. v. Wisconsin Alumni Research Found., 146 F.2d 941, 944 (9th Cir.) (suggesting that where suppression of the use of property in a patent may be against the public interest, a court of equity inay be justified in withholding relief by injunction), cert. denied, 325 U.S. 876 (1945). The court's holding, however, is not viable under current patent law. Congress has declared the particular misuse found in Vitamin Technologists-a patent holder's refusal to use or hicense its patent, id.-no longer a bar to a patent holder's request for relief from infringement. PMRA, 35 U.S.C. $\$ 271(d)(4)$ (1988).

98. Kolene Corp. v. Motor City Metal Treating, Inc., 440 F.2d 77, 85 (6th Cir.) (stating that "the misconduct must be connected with the matter in hitigation"), cert. denied, 404 U.S. 886 (1971). 
used in antitrust cases. ${ }^{99}$ But such a requirement, although rational, is clearly not the law. ${ }^{100}$

IV

\section{The Economic IrRationality of the Patent Misuse DOCTRINE}

The purpose of the patent laws is to provide inonopoly-type rewards to a single product or process in order to encourage research and cominercialization of innovation. ${ }^{101}$ The seventeen-year patent period and the patent scope limitation reflect a coinpromise between the societal need to reward (and thereby encourage) innovation, and society's economic preference for coinpetition. ${ }^{102}$ This is the patent-antitrust conflict.

The patent misuse doctrine allows competitors to infringe upon a patent misused by the patentee, without exposure to legal sanction. ${ }^{103}$ In essence, then, the doctrine pumishes patentees for choosing to misuse their patents. Apphication of the doctrine gives rise to a number of problems, which are the subject of this Part.

First, the patent misuse remedies are unrelated to the injury caused. Second, the sanctions imposed often duphcate antitrust remedies, resulting in a superoptimal level of pumshment. Finally, the lack of a standing requirement ineans that infringers who have not been imjured by misuse inay be rewarded. This may encourage patent infringement even where it is mefficient.

To enforce its patent grant, a patentee inust be able to limit infringement through legal sanction. If the patentee could not enforce his patent against infringers, it would be of no benefit to lim1. Although trade secret laws also provide soine protection for technological innovation in intellectual property, this protection is far weaker than that afforded by patent law. ${ }^{104}$ To gain trade secret protection, the inventor must main-

99. See supra text accompanying note 92 (describing the additional requirements imposed by the antitrust injury doctrine).

100. D. Chisum, supra note $67, \S 19.04$, at $19-158$.

101. F. SCHERER, supra note 63 , at 442 ("Stimulating the invention and development of new products and processes is without doubt the most important benefit expected of the patent system."); see also E. MANSFiEld, Mrcroeconomics of TEchnological InNovation 315 (1987) (according to a previous Mansfield study, "about one-half of the patented innovations would not have been introduced without patent protection").

102. See F. SCHERER, supra note 63, at 442 ("[T] he overriding issuc of patent policy is whether the benefits [to innovation] of the system outweigh the costs [to competition]."); see also Kaplow, supra note 2, at 1823-29 (length of patent protection is optimal where it maximizes the value of rewarding innovation, less the cost of patents to coinpetition).

103. See supra notes $95-96$ and accompanying text.

104. Kewanee Oil Co. v. Bicron Corp., 416 U.S. 470, 489-90 (1974) (trade secret law provides weaker protection primarily because coinpetitors can create independently, reverse engineer, or learn a secret by other mcans not easily discovered or proven, and use the secret with impunity).

Corporations apparently have found patent protection preferable to trade secret protection 
tain strict secrecy concerning the invention. ${ }^{105}$ Since in obtaining a patent an inventor inust disclose her invention to the public, she thereby loses all trade secret protection. Thus, a patentee with an unenforceable patent may be worse off than if she had received no patent at all, since the process of obtaining the patent will have precluded trade secret protection.

\section{A. Individual Remedy Problems}

In a nutshell, the patent misuse doctrine prevents a patentee froin taking legal action against infringers (and thus prevents the patentee from obtaining his reward) because of a judgment that the patentee has done soinething wrong. ${ }^{106}$ Although there is a rough sense of justice about this, ${ }^{107}$ the appearance of rationality breaks down because the sanction imposed on the patentee bears no relation to the severity of the violation. Current applications of the patent misuse doctrine to generate dainage awards resemble a lottery system: both superoptimal and suboptimial pumishinent can result.

As an illustration, consider three possible scenarios, each of which involves a patentee guilty of misuse who is suing an infringer for dainages. $^{108}$ In the first scenario, the cost to the patentee ${ }^{109}$ of continued

where the former is available. E. MANSFIELD, supra note 101, at 316 ("Clearly, firms generally prefer not to rely on trade secret protection when patent protection is possible."); $c f$. id. at 314 (suggesting that firms sometimes patent innovations when it will serve to increase competitors' imitation costs).

105. Metallurgical Indns. v. Fourtek, Inc., 790 F.2d 1195, 1199 (5th Cir. 1986).

106. The nature of the patent misuse doctrine today is discussed in some detail at supra notes $67-100$.

107. Insofar as it operates to bar injunctive relief by a plaintiff patentee because the patentee has done soinething the court considers wrong or offensive, the patent misuse doctrine can be analogized roughly to the "unclcan hands" doctrine in tort law. Merges, Reflections on Current Legislation Affecting Patent Misuse, 70 J. Pat. \& TRAdemark OfF. Soc'y 793, 797 (1988). There are two significant differences, lowever. First, the patent misuse doctrine applies to suits for damages as well as for injunctive rehief, see P. AREEDA \& L. KAPLOW, supra note 56, at 182, and therefore cannot be explained as an exercise of the court's powers of equitable discretion.

Second, the patent misuse doctrine requires no showing of relationship between the plaintiff's act and the rccovery he is deried. See supra notes 92-94 and accompanying text; infra Section IV(C). The unclean hands doctrine, on the other hand, requires some showing of such a relationship. Cf. D. Chisum, supra note 67, $\S 19.04$, at $19-94$ (noting Morton Salt plaintiff's argument, which the Court appeared to accept as fact, that the unclean hands doctrine bars recovery only if it arises from the same transaction). Thus, for example, the unclean hands doctrine would not bar a personal injury suit by a plaintiff because that plaintiff once had been convicted of a crime.

108. The problems discussed in this Part arise both when the patent misuse defense is asserted in an action for damages and in an action for injunctive rehef. The Comment will discuss the problem in the context of damages because they are more easily quantifiable.

In either case, it is important for purposes of the initial nodel to consider a patentee who has already committed misuse. I will relax that assumption in Section IV(D) to discuss deterrence and uncertainty effects.

109. If it is assumed that the patent system is necessary to promote imovation, then in the long 
infringement is greater than the cost to society of the patentee's misuse of the patent. That is, $\mathrm{C}_{\mathrm{p}}$ is greater than $\mathrm{C}_{\mathrm{s}^{*}}{ }^{110}$ In the second scenario, the cost of continued infringement is less than the cost to society from the misuse. Here, $C_{p}$ is less than $C_{s} \cdot{ }^{11}$ In the final scenario, the cost of the continued infringement is exactly the same as the cost of the patentee's misuse to society. In other words, $C_{p}$ equals $C_{s}$.

Under the patent misuse doctrine, if a patentee has misused his patent-that is, if $C_{s}$ is greater than zero ${ }^{112}$ - the courts will not award damages to the patentee for infringement. That is, the patentee will suffer a loss of $C_{p}$ in expected damages. In the first scenario, where $C_{p}$ is greater than $C_{s}$, superoptimal punishment is the result. The patentee is puinshed by $C_{p}$ in an effort to prevent injury of only $C_{s}$, since the affirmative defense of patent misuse is an all-or-nothing proposition. In the second scenario, on the other hand, suboptimal punishment results. Since $C_{p}$ is less than $C_{s}$, requiring the patentee to pay only $C_{p}$ where his misuse costs society $\mathrm{C}_{s}$ forces society to bear more of the cost of the patent misuse than the defendant himself must bear. ${ }^{113}$ Ouly in the third scenario, where $C_{p}$ happens to equal $C_{s}$, does optimal pumishment result.

Thus, optimal punishment is unlikely in the nornal case because the level of the patent misuse sanction is not related to the severity of the

run $C_{p}$ also constitutes a cost to society in the form of lost innovation. Adding this element to the cost-benefit analysis points up the patent misuse doctrine's weakness even inore starkly.

110. Such a scenario would arise, for example, where a patentee held a very important patent, but engaged in only a small amount of misuse. Such occasions no doubt occur all the time.

111. Logically, such a scenario arises whenever a patentee misuses a patent in a way that imposes great social costs, but the patentee is not greatly hurt by infringement.

At first glance, one might objeet that a patentee can never leverage a patent for more than it is worth. See R. Bork, The ANTrTrust Paradox: A Policy AT WAR WITH ITSELF 372-75 (1978). But see Kaplow, Extension of Monopoly Power Through Leverage, 85 CoLuM. L. Rev. 515, 515-39 (1985) (time lag before coinpetitors will enter a monopolized market means that a monopohist can derive benefits froin leveraging her monopoly into another market). This theoretical debate is traced at infra note 189. The debate is not relevant here, though, since $C_{p}$ does not represent the value of the patent, but rather the losses the patentee imcurs by being unable to sue for infringement. In an instance where infringement is not really feasible, whether because of first mover advantages, the nced for large capital outlays, or any other reason, a sanction of preventing infringement suits is suboptimal, simce the patentee's loss in not pursuing those suits may be less than her gains from misuse.

112. This makes the rather charitable assumption that courts find patent misuse only where such misuse has injured society. A reasonable argument can be made to the contrary, especially where courts condemn tying arrangements without proof of market power. See supra note 88 and accompanying text. If society is not injured by a patent imsuse, of course, it does not make sense to deny rehef for infringement under any circunstances, since the optimal level of deterrenee of a costless action is zero. I assumne, though, that patent misuse imposes at least some cost on society.

113. Law and economics scholars have written exhaustive analyses of the results of nonoptimal sanctions on behavior. See, e.g., W. LANDes \& R. POSNER, THE ECONOMic STRucture Of TORT LAw (1986); see also Shavell, Criminal Law and the Optimal Use of Nonmonetary Sanctions as a Deterrent, 85 Colum. L. Rev. 1232 (1985). Such problems are compounded where, as here, the sanction is paid not to the mjured party, but to an often unrelated third party who thus receives a windfall. See infra notes $125-27$ and accompanying text. 
patent misuse violation. In a normal antitrust case, a successful plaintiff will recover dainages that are related to the injury the defendant has inflicted on him. ${ }^{114}$ In any normal lawsuit, the goal is for dainages paid to equal injuries inflicted. In the patent misuse case, on the other hand, the only goal is to determine liability. Once the plaintiff proves misuse, the remedy is set without regard for injury to the infringer or to society.

\section{B. Cumulative Remedy Problems}

The optimal sanction problems inherent in the patent misuse doctrime itself are compounded by the fact that patent misuse overlaps in many cases with the antitrust laws. Since the misuse doctrine and the antitrust laws are driven by independent policies, ${ }^{115}$ recovery under one doctrine is no bar to recovery on independent grounds under the other, even though the underlying misuse by the patentee is the same. ${ }^{116}$ Indeed, the two doctrimes can and often do coexist in a single case. ${ }^{117}$

The resnlt is a form of dual sanction for anticompetitive beliavior, which results in systematic superoptimality of punishment (and consequent underdeterrence of infringement). An infrimger who claims patent misuse will often be able to allege an antitrust violation as well, by filing a counterclaim. ${ }^{18}$ Any benefit an infringer receives from proving patent misuse and blocking an infringenent action would be in addition to its antitrust reinedies based on mjury. ${ }^{119}$

114. Under the antitrust laws, successful antitrust plaintiffs can receive treble damages plus attorney's fees. 15 U.S.C. $\S 15$ (1988). This provision has been criticized by numerous commentators. See, e.g., R. POSNER, supra note 73, at 226; Jorde \& Teece, Innovation, Cooperation and Antitrust: Balancing Competition and Cooperation, 4 HIGH TECH. L.J. 1, 49 (1989) (suggesting that treble damages are unwarranted in the context of cooperative joint ventures designed to promote innovation). Whatever the merits of this kind of damage system, it is nonetheless preferable to one in which damages are completely unrelated to the severity of the violation.

115. See supra note 82 and accompanying text.

116. Indeed, the Supreme Court originally assumed that misuse of a patent was itself a per se violation of the antitrust laws. See Mercoid Corp. v. Mid-Continent Inv. Co., 320 U.S. 661, 668-71 (1944) (Mercoid I) (conjoining antitrust and misuse freely in analysis); D. CHisum, supra note 67, $\$ 19.04$, at $19-96$ (same). Such a view necessarily implies that an infringer can seek both kinds of relief. While the conclusions of the Mercoid cases were rejeeted by Congress in 35 U.S.C. $\$ 271(d)(1)-(3)$ (1988), Congress has never made patent misuse and antitrust exclusive remedies.

117. See e.g., Zenith Radio Corp. v. Hazeltine Research, Inc., 395 U.S. 100, 140-41 (1969) (remanding for consideration of whether a patentee guilty of misuse also violated the antitrust laws).

118. The patent misuse doctrine might still play a positive role in those cases where there is no antitrust violation. The usefulness of the doctrine under those circumstances is discussed further in Part VI, infra.

119. Indeed, given the fact that private antitrust plaintiffs can receive treble damages, the risk of overdeterrence is compounded. Patent misuse would be a useful sanction if the antitrust laws systematically undercompensated plaintiffs or failed to apply at all. I am aware of no hiterature suggesting that the antitrust laws systematically undercoinpensate. For examples of the abundant literature to the contrary, see sources cited supra note 114. Underdeterrence stemming from the complete failure of the antitrust laws to purish certain types of conduct is discussed separately in Part VI, infra. 
Although they do not deal directly with the economic irrationality problem, Professors Merges and Calkins both suggest that the patent misuse doctrine may be justified as a tool of equitable discretion. ${ }^{120}$ While there are a number of specific problems with this argument, ${ }^{121}$ the inajor difficulty in applying this idea arises from the overlap between the patent misuse doctrine and the antitrust laws. If the goal of the patent misuse doctrine is to prevent unfairness, ${ }^{122}$ it should apply only where the antitrust laws do not. Since its use in areas of overlap with antitrust law generally produces superoptimial sanctions, the Merges and Calkins theory may justify the doctrine only in the limited range of cases where there is no such overlap. ${ }^{123}$

\section{Problems of Standing and Injury}

A further problem with the patent misuse doctrine is that the sanction is not necessarily "paid" to those injured by the patentee's anticompetitive acts, as it would be im a private antitrust suit or (indirectly, by benefiting consumers) in a government suit. ${ }^{124}$ Instead, it often provides a windfall to the patent infringer, who is herself a wrongdoer. Under current law, the patent infringer can take advantage of the patent misuse

120. Merges, supra note 107, at 796-98; see also Calkins, supra note 7, at 187 (suggesting that patent misuse doctrine is designed to prevent a patentec from projecting the economic effects of her valid grant beyond the limits of her legal monopoly).

121. First, despite its roots, the patent misuse doctrine is not one of "equitable discretion"; mdeed, it does not involve judicial discretion at all. An infringer who proves misuse is entitled to have the court refuse to aid the patentee. Morton Salt Co. v. G.S. Suppiger Co., 314 U.S. 488, 494 (1942) (a "patentee ... may not claim protection of his grant" where he has misused patent); accord D. CHISUM, supra note $67, \S 19.04$, at $19-91$ ("If such misuse is found, the courts will with hold any remedy ....") (emphasis added). Thus, any "discretion" the court may possess is only in finding the misuse.

Second, the patent misuse doctrine is not limited to cases in which the patentee seeks equitable retief (i.e., an injunction against continued infringeinent), but apphes to damages actions as well. See supra note 67. Fimally, the traditional requirements that a petitioner in equity show "irreparable harm" and the absence of an adequate remedy at law, Smith v. Western Elec. Co., 643 S.W.2d 10, 13 (Mo. Ct. App. 1982), are notably absent from patent misuse cases. Indeed, as noted above, an infringer need not show harm at all to get the benefit of the doctrine, see supra Section III(C), and can get patent misuse relief regardless of the availability of antitrust damages.

122. Unfairness to whoin is an open question, simce the infringer need not herself be injured to take advantage of the patent misuse defense. For a discussion of the fairness rationale as a justification for optimizing sanctions, see infra Section IV(D).

123. For a discussion of the contimued vitality of the patent misuse doctrine where the antitrust laws do not apply, see infra Part VI.

124. To have an antitrust claim for misuse, an infringer will have to slow antitrust injury, and the problem discussed $\mathrm{m}$ this Section will not arise. It is precisely where an infringer has both an antitrust and a misuse claim, though, that the cumulative overdeterrence problems discussed in the previous Section arise. Thus, the standing problem arises only where the systematic overdeterrence problems of Section IV(B) do not arise, and vice versa. An infringer will either have an antitrust claim against a patentce or not. If she does, overdeterrence will result from the dual sanction. If, on the otlier hand, the infringer could not liave brought an antitrust suit, the problems discussed in this Part will arise. 
doctrine whether or not she has been injured by the patentee's misuse. ${ }^{125}$ In effect, the patent misuse doctrine creates a scheme of royalty-free compulsory licensing where a patentee is guilty of misuse.

The lack of an injury requirement often produces situations im which parties who were not injured by misuse are the ones who benefit from the doctrine. Besides annulling any coinpensatory effect the remedy might have, this undermines the goals of the patent system, simce it unnecessarily rewards (and therefore encourages) infringeinent. Parties unrelated to the patentee's wrongful acts inay infringe its patents with impunity, since they are protected from hability by the patent misuse doctrine. Indeed, because the bar on infringeinent suits contimues until the wrongful consequences have been dissipated fully, ${ }^{126}$ a finding of misuse essentially gives a green hight to infringers of that patent for the foreseeable future.

On the other hand, traditional antitrust damages both appropriately sanction the patentee without stripping away her reward, and pay that compensatory sanction to injured rather than uninjured parties. As one lower court stated before the developinent of the patent imisuse doctrine,

It is difficult to understand how or why a violation of the Sherman anti-trust law by this complainant, if there has been such a violation, confers any right on the defendant to infringe this patent. That act points out the penalties for its violation, and it is not understood that such law demies the grantees of patents the protection of the law because they may be violating some statute. ${ }^{127}$

Yet this is precisely what the patent misuse doctrine does.

\section{The Consequences of Nonoptimal Sanctions}

There are two forns of potential wrongdoing at work im patent misuse cases: the imsuse of the patent and the infringeinent of the patent. Optimization within the patent-antitrust intersection requires providing the correct level of deterrence for both types of conduct. Both underdeterrence and overdeterrence are therefore inefficient in this context. The problems with underdeterrence of misuse are easy to see. If a patentee is not sufficiently deterred by apphication of the patent misuse

125. See supra notes $92-94$ and accompanying text. Scholars and some early cases have suggested allowing the defense only when the alleged misuse is related to the patent being infringed. See, e.g., R.C.A. v. Hygrade Sylvania Corp., 10 F. Supp. 879, 882 (D.N.J. 1934); 7 J. voN

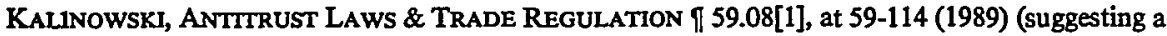
standing requirement). This, of course, is not the same as requiring a showing of ijury to the infringer, simce it merely requires proof that the same patent is at issue in each case. Requiring imjury to the infringer would amount to requiring a showing of "patent misuse injury" similar to the antitrust injury requirement currently in effect. See supra note 92 and accompanying text.

126. P. AREedA \& L. KAPLOW, supra note 56, at 182-83; D. Chisum, supra note 67, $\$ 19.04$, at $19-91$.

127. General Elec. Co. v. Wise, 119 F. 922, 924 (C.C.N.D.N.Y. 1903). 
doctrine, she will continue to misuse her patent. ${ }^{128}$ Because she is misusing her patent, the courts will not enforce the patent, and infringement will be underdeterred as well. ${ }^{129}$

The problems with overdeterrence are less obvious. At first glance, one might be tempted to conclude that because overdeterrence of misuse will prevent future misuse and thus allow infringement suits to contimue, it is efficient. This is not so. Overdeterrence imposes substantial costs on protected activity that might mistakenly be construed as misuse, both because of uncertainty over the exact scope of the law and because of risk aversion. ${ }^{130}$ Overdeterrence, almost by definition, is inefficient.

In addition to efficiency consequences, fairness problems also mhere in a doctrine in which the expected sanction bears no real relation to the magnitude of the offense. In the first place, the very arbitrariness of such a scheine may offend our sense of proportionality, and may be perceived as unfair in an individual case even if it deters efficiently overall. ${ }^{131}$ Furtherinore, it might be the case that certain groups are systematically over- or underdeterred. Systenatic unfairness, even more than arbitrariness, is likely to offend our sense of justice. ${ }^{132}$

The consequences of the patent misuse doctrine, then, are troubling for both fairness and efficiency reasons. Absent soine justification for inaintaining the patent misuse doctrine, the problems discussed im this Part cast serious doubt on its utility.

\section{$\mathrm{V}$ \\ Legislative Proposals for Reform}

In the last two years, there has becn a flurry of congressional activity aimed at reforming the patent misuse doctrine. Although all this activity has been directed towards limiting the scope of the doctrine, different bills have taken at least three distimct conceptual approaches. This Part

128. Society has made a judgment that patent misuse is bad, largely (but not entirely) because of its anticompetitive consequences. See supra notes 101-05 and accompanying text.

129. Society, balancing the competing goals of innovation and competition, has also decided that the enforceability of a patent for a limited period of time is efficient. See supra notes 101-02 and accompanying text.

130. Block \& Sidak, The Cost of Antitrust Deterrence: Why Not Hang a Price Fixer Now and Then?, 68 GEo. L.J. 1131, 1133-38 (1980). As an example of overdeterrence, consider what would happen (besides, of course, a trcinendous increase in lawyers' incomes) if California imposed the death penalty for speeding. Speeding would be deterred, certainly, but driving at legal speeds approaching the speed limit would also be deterred. Indeed, people might choose not to drive at all. Assuming we think some driving is efficient, we ought not to sanction speeding without regard to the consequences it will have. Neither ought we blindly to sanction misuse.

131. See Michelman, Property, Utility, and Fairness: Comments on the Ethical Foundations of "Just Compensation" Law, 80 HARv. L. REV. 1165, 1214-15 (1967) (discussing "demoralization costs" which result because people perceive their losses as unfair).

132. See, e.g., J. RAWLS, A THEORY OF JUSTICE 60-61 (1971). For a discussion of situations in which systematic unfairness might arise, see supra note 111. 
will describe each of these approaches in turn, by examining seven bills from the 100th and 101st Congresses. ${ }^{133}$ Although most of the bills did not pass, they are important to examine because they are paradigmatic of current approaches to patent reform.

\section{A. Tracking Antitrust Law}

The first category of reform efforts, characterized by S. 1200 and the second part of S. 438, is the inost general. This approach would limit the application of the patent misuse doctrine to conduct that also violates the antitrust laws. ${ }^{134}$ In other words, an infrimgement defendant claiming patent imsuse would have to prove an antitrust violation to benefit froin the patent imsuse doctrine. Thus, one could no longer prove tying, for example, without also showing market power.

The idea of limiting the scope of the patent misuse doctrine to that of the antitrust laws received support from several prominent antitrust experts. ${ }^{135}$ Supporters of S. 438 advanced two major arguments for this proposal: it would provide increased certainty in the application of the patent misuse doctrine, and it would narrow the doctrine's scope. ${ }^{136}$ of course, the first argument is true ouly to the extent that the antitrust laws themselves are relatively more "certain" in application than is the patent misuse doctrime. The second argument is undoubtedly correct, simce, as

133. The bills are S. 198, 101st Cong., 2d Sess. (1990); H.R. 469, 101st Cong., 1st Sess. (1989); S. 270, 101st Cong., 1st Sess. (1989); H.R. 4972, 100th Cong., 2d Sess. (1988); H.R. 4086, 100th Cong., 2d Sess. (1988); S. 1200, 100th Cong., 1st Sess., 133 CoNG. Rec. S6481 (1987); S. 438, 100th Cong., 2d Sess., 133 Cong. Rec. S1597 (1987). The 100th Congress did not pass bills S. 438, S. 1200, or H.R. 4086. H.R. 4972 was passed as the Patent Misuse Reform Act of 1988, Pub. L. No. 100-73, 102 Stat. 4674 (codified at 35 U.S.C. § 271(d)(4)-(5) (1988)). See D. Chisum, supra note 67, $\S 19.04$, at 19-101 to 19-102; Calkins, supra note 7, at 196-97. The 101st Congress did not pass bills S. 270 or H.R. 469, but did pass S. 198, which contained similar provisions regarding market power. Senate Passes Antitrust Legislation on Treatment of Intellectual Property, 59 ANTTTRUST \& TRADE REG. REP. 600 (Oct. 25, 1990) [hereinafter Antitrust Legislation].

134. See S. 438, 100th Cong., 2nd Sess., $§$ 201(a) (1988) (patent ownership is not presumptive of market power); S. 1200, 100th Cong., 1st Sess. (1987) ("[N]o patent owner ... shall be . . deemed guilty of misuse ... unless such practices ... violate the antitrust laws."); Merges, supra note 107, at 793 (S. 1200 tests "all alleged patent misuse offenses under antitrust standards"); accord Calkins, supra note 7, at 193.

135. These supporters included Judge Posner of the Seventh Circuit Court of Appeals and John Bolton, then-Assistant Attorney General at the U.S. Department of Jnstice. In USM Corp. v. SPS Technologies, Inc., 694 F.2d 505 (7th Cir. 1982), cert. denied, 462 U.S. 1107 (1983), Judge Posner wrote:

If misuse claims are not tested by conventional antitrust primciples, by what primciples shall they be tested? Our law is not rich in alternative concepts of monopolistic abuse; and it is rather late in the day to try to develop one without in the process subjecting the rights of patent holders to debilitating uncertainty.

Id. at 512. The Department of Justice endorsed S. 438 for much the same reason. Calkins, supra note 7, at $196 \mathrm{n} .60$ (citing letter from John Bolton stating that courts mnst take care not to "interfere with procompetitive patent hicensing").

136. See Calkins, supra note 7, at 196 (examining in detail the legislative history of S. 438). 
noted above, the patent misuse doctrine is currently apphed even where the courts would not find an antitrust violation. ${ }^{137}$ A third justification for such legislation, although not a reason advanced by the legislative sponsors, is that eliminatimg differential standing requirements would prevent substantive outcomes from depending on whether the patentee is a plaintiff or a defendant.

S. 1200 would have gone one step farther than S. 438 in limiting the scope of the patent misuse doctrine. Like S. 4.38, S. 1200 would have limited the patent misuse defense to cases in which an antitrust violation existed. ${ }^{138}$ In addition, S. 1200 would have introduced an unreasonableness requirement for every claim of patent misuse, including those acts that the antitrust laws would declare illegal per se. The effect of such a change is unclear. ${ }^{139}$

The imtroduction of an unreasonableness requirement would be, in my view, equivalent to requiring the application of the "rule of reason" (used in certain types of antitrust violations) to all patent misuse violations, even those that would be illegal per se under the antitrust laws. ${ }^{140}$ Although a proposal to evaluate all antitrust and patent inisuse claims under the rule of reason may have some merit, S. 1200 merely reverses

137. See supra notes 80-94 and accompanying text.

138. Patent Licensing Reform Act of 1988: Hearing on H.R. 4086 Before the Subcomm. on Courts, Civil Liberties, and the Administration of Justice of the House Comm. on the Judiciary, 100th Cong., 2d Sess. 37 (1988) [hereinafter Licensing Hearingl (statement of Rene D. Tegtmeyer, Ass't Comm'r for Patents) (distinguishing aspects of S. 1200).

139. See Merges, supra note 107, at 799 n.7 (expressing a fear that use in H.R. 4086 of the term "unreasonable" in connection with resale price maintenance and price fixing "might open the door to serious mischief"). The unreasonableness language of H.R. 4086 is analogous to that of S. 1200. Thus, Professor Merges' criticism of the unreasonableness requirement of the House bill seems to apply as well to the Senate proposal.

While Professor Merges does not himself believe that H.R. 4086 intended to abolish per se analysis in patent cases, he does acknowledge the anbiguity raised by the bill's language, and suggested at the time that it be ainended. Id.; see infra note 140 .

140. Professor Merges apparently sees a distinction between the antitrust "rule of reason" and the "unreasonableness" requirement of S. 1200. Merges, supra note 107, at 799 n.7. He does not, lowever, say what that distinction might be. Even if a distinction does exist, the very existence of an "unreasonableness" requirement inust mean that some practices falling within the hiteral definition of patent misuse will avoid being sanctioned because they are "reasonable." Otherwise, the "unreasonableness" requirement would merely be excess verbiage. The unreasonableness rule, lowever different it may be from the rule of reason, is necessarily at odds witl the fundainental idea that the practice is per se illegal.

The fact that patent misuse is treated differently from an antitrust violation under $\mathbf{S .} 1200$ does

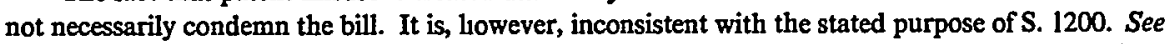
id. at 793 (goal of S. 1200 is to test patent misuse nnder antitrust standards). Possible justifications for differential treatunent of the patent misuse doctrine are discussed in Part VI, infra.

One could, of course, recommend that the antitrust laws be clianged as well. See, e.g., Note, Standard Antitrust Analysis and the Doctrine of Patent Misuse: A Unification Under the Rule of Reason, 46 U. PrTT. L. REv. 209, 210 (1984) (authored by Byron A. Bilicki) (recommending rule of reason analysis for both antitrust law and the patent nisuse doctrine). 
the consistency problem of the current system. ${ }^{141}$

The current system declares some practices illegal per se under the patent laws, even though the same practices would be subject to the rule of reason under the antitrust laws. Thus, patent misuse is easier to prove in these cases than would be the equivalent antitrust violation. ${ }^{142}$ But $S$. 1200 , to the extent that it requires a uniform rule of reason analysis of patent misuse, makes it easier to prove those antitrust violations that are per se illegal than to prove patent misuse. Thus, under S. 1200 as under current law, substantive outcomes depend on whether a claim is for an antitrust violation or for patent misuse.

The defeat of both these bills in the 100th Congress indicates that patent misuse and antitrust law still require different elements of proof. ${ }^{143}$ It is also clear that, Judge Posner's suggestions to the contrary notwithstanding, the courts continue to apply public policy standards set by patent rather than by antitrust law to patent misuse cases. ${ }^{144}$

\section{B. Ad Hoc Approaches}

A second category of patent misuse reform legislation takes an ad hoc approacli to the perceived probleins of the doctrine. Typical of this group are bills that change one specific policy or presumption in preexisting law, or reverse a single line of cases, witlout making consistent structural changes in the doctrine. In some cases, the bills claim merely to codify or clarify existing law. Two bills from the 100th Congress epitomize this approach: H.R. 4972 (enacted by Congress as the Patent Misuse Reforin Act of 1988 (PMRA)) ${ }^{145}$ and H.R. 4086. ${ }^{146}$

The PMRA added two restrictions to the existing inverse codification of the patent misuse doctrine. ${ }^{147}$ First, it provides that patentees sliall not be guilty of misuse because thcy "refused to license or use any rights to the patent ...."148 Altlough Professor Calkins suggests that Congress intended only to codify existing case law, ${ }^{149}$ and although most case law lias upleeld a patentee's riglt to suppress lier patent, ${ }^{150}$ courts

141. For a fuller discussion of the consistency problem, see supra Part IV.

142. Tying arrangements are a paradigmatic example, since antitrust (but not patent misuse) requires proof of market power to constitute a violation. See supra notes 86-91 and accoinpanying text.

143. See Calkins, supra note 7, at 196 (discussing implications of Congress' rejection of S. 438).

144. Id.

145. 35 U.S.C. $\S 271(d)(4)-(5)$ (1988).

146. H.R. 4086, 100th Cong., 2d Sess. (1988).

147. For a discussion of the restrictions in place before the 1988 additions, see supra notes $69-77$ and accompanying text.

148. 35 U.S.C. \& 271(d)(4) (1988).

149. Calkins, supra uote 7, at 197.

150. See, e.g., Continental Paper Bag Co. v. Eastern Paper Bag Co., 210 U.S. 405, 424 (1908) (patentee is owner of lier product and may withhold it from public); SCM Corp. v. Xerox Corp., 645 
have never universally accepted this approach. ${ }^{151}$ Thus, section (d)(4) of the PMRA niay either clarify or change existing case law.

The second section of the PMRA, section (d)(5), requires proof of market power in the tying product ${ }^{152}$ in order for a tying arrangenient to constitute patent misuse. ${ }^{153}$ This section clearly reverses existing patent misuse law in the case of tying arrangenents and brings that law into rough conformity with antitrust law, which also requires proof of inarket power in tying cases. ${ }^{154}$

The operation of section (d)(5), however, produces inconsistencies between patent misuse and antitrust. First, to prove patent misuse, section 271(d)(5) requires a showing that the patentee has niarket power in her patent. But the Supreine Court has long presumed (inaccurately, in my view) ${ }^{155}$ that a patentee by definition has inarket power in her patent or patented product for purposes of evaluating antitrust claims. ${ }^{156}$ Thus, sincc defendants asserting patent misuse defenses cannot avail theinselves of a presumption of the patentee's market power, the PMRA appears to require a stronger showing for patent misuse violations than the courts

F.2d 1195, 1204 (2d Cir. 1981) (mere exercise of right of exclusivity granted by patent law, through a refusal to license, is permissible), cert. denied, 455 U.S. 1016 (1982).

151. See Vitamin Technologists, Inc. v. Wisconsin Alumni Researcls Found., 146 F.2d 941, 944 45 (9th Cir. 1944) (suggesting that refusal to license might itself constitute patent misuse), cert. denied, 325 U.S. 876 (1945).

152. The tying product is the product that purchasers want to buy, and the tied product is the product that purchasers are compelled to buy in order to get the tying product. In patent misuse cases, the tying product is necessarily the patented product.

153. 35 U.S.C. $\$ 271$ (d)(5) (1988) provides that a patentee shall not be deemed guilty of misuse because she

conditioned the license of any rights to the patent or the sale of the patented product on the acquisition of a license to rights in another patent or purchase of a separate product, unless, in view of the circumstances, the patent owner has market power in the relevant market for the patent or patented product on which the license or sale is conditioned.

154. See Jefferson Parish Hosp. Dist. v. Hyde, 466 U.S. 2, 13-14 (1984) (Antitrust law condemns use of market power to "force a purchaser to do soinething that he would not do in a coinpetitive market."). Whether section 271(d)(5) has made the scope of the two doctrines the same is uncertain. In Jefferson Parish, four Justices who concurred in the result contended that the rule of reason sliould govern antitrust tying cases but that three preliminary slowings-the existence of two distinct product markets, market power in the tying product, and a substantial threat of acquiring market power in the tied product-were necessary before reaching the rule of reason analysis. Id. at 41 (O'Connor, J., concurring in the judgment).

The majority rejected the rule of reason approach, using instead what they called a per se rule where market power is proven. Id. at 15-16. However, because the inajority never indicated a position on the relevance of the other two preliminary showings mentioned in the concurrence, the precise shape of antitrust tying law is not clear at this time. As a result, it is unclear whether section $27 i(d)(5)$ brought the two doctrines completely into line or not.

155. See infra note 181 and accompanying text. For recent congressional proposals to change this presumption, see infra Section V(C).

156. See, e.g., Jefferson Parish, 466 U.S. at 16 ("For example, if the Government has granted the scller a patent or similar inonopoly over a product, it is fair to presume that the inability to buy the product elsewhere gives the seller market power."); U1rited States v. Loew's, Inc., 371 U.S. 38, 45 (1962) ("The rcqurisite cconomic power is presumed when the tying product is patented . . . ."). 
have for antitrust violations. ${ }^{157}$

Second, under Senator DeConcini's reading, section 271(d)(5) eliminates the per se rule in all patent misuse tying cases, instead applying the rule of reason. ${ }^{158}$ If true, this would make the requirements for finding patent misuse more stringent than those for finding an analogous antitrust violation. Professor Calkins apparently finds some support for this reading in the legislative history of section 271 (d)(5). ${ }^{159} \mathrm{It}$ is far from clear, however, that the plain meaning of the statute will bear such an interpretation. ${ }^{160}$ All that can be concluded definitively is that this section reduces the scope of the patent misuse doctrine in the tying area by permitting ties iniposed by patentees who lack market power.

H.R. 4086, which also adopted an ad hoc approach, was far more comprehensive. This bill would have codified the entire patent misuse doctrine affirmatively for the first time. In addition, its provisions would have required heightened proof for certain types of patent misuse, ${ }^{161}$ and would have created safe harbors for certain conduct. ${ }^{162}$ Although H.R. 4086's sponsor claimed that the bill's purpose was merely to adopt the current court rules governing patent misuse, ${ }^{163} \mathrm{im}$ fact it would have made some significant changes.

H.R. 4086 section (d)(2) would have defined the activities that constitute patent misuse. Tying arrangements would have constituted misuse where the patent owner has market power in two situations: where the tied product was unpatented ${ }^{164}$ and where the tied product was patented but also "unreasonably" tied. ${ }^{165}$ Unreasonably fixing prices or resale prices, ${ }^{166}$ and unreasonably iniposing noncompetition

157. Thus, section 271(d)(5) merely reverses the inconsistency between patent misuse and antitrust with respect to market power proof, much the same way $S .1200$ reversed the inconsistency with respect to per se/rule of reason analysis. See supra text accompanying notes $140-41$.

158. 134 CoNG. REC. S17147 (daily ed. Oct. 21, 1988) (statement of Sen. DeConcini). Such a view would put the patent misuse doctrine at odds with antitrust law on this question. For a discussion of antitrust law concerning tying arrangements, see supra note 154.

159. Calkins, supra note 7, at 198-99. Senator DeConcini's statements can hardly be considered authoritative legislative history, since he was not a sponsor of the bill and was not in the originating chamber; in fact, he had put forth a competing bill (S. 438). Id. at 198.

160. By its terms, section 271(d)(5) merely prohibits a finding of patent misuse through tying, except when the patentee has market power. As the majority in Jefferson Parish made clear, this is not the same as applying the rule of reason test. 466 U.S. at 15-16 (applying what the court called a "per se rule" where plaintiff proves market power); see also supra note 154.

161. See infra notes $164-69$ and accompanying text.

162. See infra notes $\mathbf{1 7 0 - 7 2}$ and accompanying text.

163. Licensing Hearing, supra note 138, at 8 (statement of Rep. Kastenmeier) ("The basic thrust of the bill is to restate in statutory language much of the judicially developed doctrine of patent misuse.").

164. Id. at 3, 1l. 14-18.

165. Id. 11. 22-24. This new, two-tiered approach to tying parallels neither antitrust law nor the preexisting patent misuse doctrine.

166. Id. at 4, 11. 4-6. This provision would make patent misuse harder to prove than an antitrust 
agreements, ${ }^{167}$ extension agreements, ${ }^{168}$ or grant-back clauses ${ }^{169}$ also would have been considered misuse under H.R. 4086. Section (d)(3) also created safe harbors for certain conduct. In addition to those activities already protected by section 271(d), H.R. 4086 would have legalized refusal to license or use patent rights, ${ }^{170}$ price-discrimination im setting hicense royalties, ${ }^{171}$ and miposition of territorial or field-of-use restrictions on hicenses. ${ }^{172}$

Thus, like PMRA, H.R. 4086 took a case-by-case approacl to the revision of the doctrine (although it had the advantage of codifying patent misuse affirmatively rather than negatively). H.R. 4086 would liave changed existing patent misuse law in a number of ways, generally limiting its scope, but not in a way that would have paralleled current antitrust doctrine. Professor Merges endorsed the general approach of H.R. 4086 for precisely this reason: it preserved the vitality of the patent misuse doctrine as mdependent from antitrust law. ${ }^{173}$ As discussed above, though, such a piecemeal approach does little to resolve the current problems witl the patent misuse doctrine. ${ }^{174}$

\section{Market Power Definitions}

The final legislative reform effort lias been directed at a muclı more limited target-the antitrust presumption that patent holders also hold market power. Two identical bills introduced in the 101st Congress, S. 270 and H.R. 469, provided that patents and copyrights "sliall not be presumed to define a market or to establish market power, including economic power . . . or monopoly power." 175 In late 1990, botll the House and the Senate passed versions of S. 198, which provided that an intellectual property right "shall not be presumed to define a market or establislı market power."176 Because tlie versions were not identical, however, tlie

violation, since antitrust law makes price fixing and resale price maintenance illegal per se. See supra note 42 and accompanying text. For a discussion of similar "unreasonableness" provisions in S. 1200 , see supra notes $139-40$.

167. Licensing Hearing, supra note 138, at 3, 11. 19-21.

168. Id. 11. 25-26; id. at 4, 11. 1-3.

169. Id. at 3, 11. 7-13.

170. Id. at 5, 11. 3-4. A similar provision was eventually aclopted in the PMRA as 35 U.S.C. $\S 271(\mathrm{~d})(4)$ (1988).

171. Licensing Hearing, supra note 138, at 5, 11. 5-12.

172. Id. 11. 13-15.

173. Merges, supra note 107, at 793 ("[T] he House bill, H.R. 4086, is superior [because] . . [i]t retains the special characteristics of patent misuse as an equitable doctrine distinct from antitrust law ...."). The continued vitality of the patent misuse doctrine will be discussed in greater detail in Part VI, infra.

174. See supra Part IV.

175. S. 270, 101st Cong., 1st Sess. § 2 (1989); H.R. 469, 101st Cong., 1st Sess. $§ 2$ (1989).

176. S. 198, 101st Cong., 2nd Sess. (1990); see Antitrust Legislation, supra note 133, at 600. S. 438, which contained similar language, was defeated in 1988. Calkins, supra note 7, at 196. 
bill did not become law and died at the end of the 101st Congress. ${ }^{177}$ Since both houses of Congress agreed by voice vote to the relevant provisions, however, approval of a similar bill in the next Congress seems likely.

Such legislation would not directly change the patent misuse doctrine. Instead, it would change the antitrust presumption about the market power of patents-a presumption created by cases such as United States v. Loew's, Inc. ${ }^{178}$ and Jefferson Parish Hospital District v. Hyde. ${ }^{179}$ This change would bring the antitrust laws into conformity with section 271(d)(5), which requires proof of market power in order to establish patent misuse. In this one area, therefore, the inconsistency between the antitrust and patent misuse laws would be eliminated. But it would be antitrust law that changed, rather than its patent misuse counterpart. ${ }^{180}$

In addition to eliminating mconsistencies between antitrust and patent misuse, the proposed change would benefit current antitrust law. Nuinerous commentators, mcluding such luminaries as Professors Scherer and Hovenkamp, have spoken out against the market power presumption, largely because no evidence shows that patent grants confer power in a relevant product market. ${ }^{181}$ In any event, regardless of its effects on antitrust law at a micro level, abohshing the market power

177. The Senate passed S. 198 on May 1, 1990. On September 27, 1990, the House approved S. 198 with amendments, merging H. 5498 into the Senate bill. On October 19, 1990, the Senate passed the revised House version of $S$. 198, but added new amendments to the House amendments. 1 Cong. Index (CCH) S 328 (Nov. 9, 1990); 2 Cong. Index (CCH) H 5506 (Nov. 9, 1990). Because the two houses never agreed on the same version of the bill, it died when the congressional session ended on October 26, 1990.

178. 371 U.S. 38 (1962).

179. 466 U.S. 2 (1984). For a description of these antitrust presumptions, see supra notes 155 56 and accompanying text.

180. S. 198 also provided that antitrust plaintiffs could show market power by "a preponderance of the evidence indicating that there are no substantially equivalent or substitutable products or processes." Antitrust Legislation, supra note 133, at 600 . It is not clear whether or how this would differ from the cross-elasticity of demand test normally used in defining product markets. See Lemley, United States v. Syufy: Bad Economics in the Northern District of California, 20 ANTTRRUST L. \& ECON. Rev. 9, 13-14 (1989) (discussing cross-elasticity test in the context of a monopolization case).

181. See, e.g., H. Hovenkamp, Economics AND Federal ANTtTrust Law § 8.3, at 219 (1985) ("Many patents confer absolutely no market power on their owners.... The economic case for 'presuming' sufficient market power . . . is very weak."); Nat'1 Inst. on Indus. \& Intellectual Prop., The Value of Patents and Other Legally Protected Commercial Rights, 53 ANTTTRUST L.J. 535,547 (1985) ("Statistical studies suggest that the vast najority of all patents confer very hittle monopoly power."); Note, The Presumption of Economic Power for Patented and Copyrighted Products in Tying Arrangements, 85 CoLUM. L. REv. 1140, 1156 (1985) (authored by William Montgomery) ("More often than not, however, a patent or copyright provides little, if any, narket power."); see also P. AREEDA \& L. KAPLOW, supra note 56, at 441 (suggesting that $80-90 \%$ of all patents may be without any commercial value, much less any market power); Scherer, supra note 62, at 44-47 (lack of commercial value of most patents negates utility of compulsory licensing). 
presumption would not fundamentally alter the patent misuse doctrine or its relationship to antitrust law.

Because fundamental economic probleıns requiring reform exist in the patent misuse doctrine and its relationship to antitrust law, this Comment takes the position that both Professor Merges' arguments and the current legislative reform efforts largely miss the point. Even those reforms that would make patent misuse law conform to antitrust law fail to address the unique remedial structure of the patent misuse doctrine. In fact, none of the recent legislation addressed the fundamental economic problems discussed in Part IV.

\section{VI \\ The Continuing Vitality of the Patent Misuse DOCTRINE}

The problems with the patent misuse doctrine counsel against its use, at least where it overlaps with the antitrust laws. ${ }^{182}$ The reinaining question, then, is whether the doctrine retains any independent vitality, or whether it should be scrapped altogether. While no scholarship has examined the patent misuse doctrine from a remedial perspective, some commentators have suggested limiting the doctrine or abandoning it entirely. ${ }^{183}$

Professor Merges believes that the differences between the patent misuse doctrine and the antitrust laws justify the continued existence of both. ${ }^{184}$ I think such a position is untenable for two reasons. First, even the "limited vitality" approach advocated by Professor Nicoson ${ }^{185}$ would solve ouly the cumulative economic probleins described in Section IV(B). It would do nothing to solve the over-/underdeterrence or standing problems inherent in the patent misuse remedy.

Second, neither Merges nor Nicoson suggests palatable solutions for

182. The conclusions reached in Section IV(B) suggest that if the patent misuse doctrine is to continue, it should continue only in areas the antitrust laws do not reach. Thus, an approach like that found in S. 1200, which atteinpts to equate antitrust and patent misuse, is inisguided not only because it fails to address the economic probleins of the patent misuse defense, but also because it eliminates those parts of the doctrine least subject to economic criticism.

183. Compare Merges, supra note 107, at 795-98 (suggesting that the patent misuse doctrine shonld be retained apart from the antitrust laws because it provides the flexibility of "equitable discretion") with Nicoson, Misuse of the Misuse Doctrine in Infringement Suits, 9 UCLA L. REV. 76, 109-10 (1962) (recommending that the patent misuse doctrine be limited to cases in which the antitrust laws do not apply) and with Note, supra note 140, at 210 (concluding that the patent misuse doctrine should be coterminous with the antitrust laws). As demonstrated in Parts IV and VI, I wonld at the very least limit the patent misuse doctrine along the lines Professor Nicoson suggests.

184. Merges, supra note 107, at 797.

185. See Nicoson, supra note 183, at $109-10$ ("application of the misuse doctrine should be limited to those eases in which the plaintiff has used his patent in subversion of the underlying purpose of the patent system"). 
determining which areas of the patent misuse doctrine have independent validity and should be retained. As noted above, ${ }^{186}$ the patent misuse doctrine differs in application from antitrust law in three inajor ways: it prohibits certain activities (including, until recently, refusal to heense) that do not violate the antitrust laws; it allows a finding of misuse on proof of certain antitrust violations without a showing of narket power or anticoinpetitive injury; and it allows an infringer to benefit froin the doctrine without having to prove injury froin the misuse. A general assertion that the patent misuse doctrine should retain limited vitality does nothing to reconcile the specific divergences between the two areas of law.

Professor Merges offers as examples three practices he believes justify the continued existence of the patent misuse doctrine. They are tying arrangements, grant-back clauses, and extensions of heense agreements beyond the patent term. ${ }^{187}$ Merges suggests that inarket power should not be required to prove a tying arrangement, because markets for patents are "thin." 188 But even if true, this argument does not suggest that the market power requirement should be rejected, but merely that courts inust take inore care when defining the relevant inarket.

Second, even Merges avoids suggesting that tying without inarket power hurts competition (or any other value protected by the patent systein). ${ }^{189}$ Since antitrust law prohibits tying with inarket power, though, Professor Merges offers no reason for wanting to extend patent misuse beyond the current scope of the antitrust laws. Thus, the "solution" of the patent misuse doctrine is no solution to this problein at all; instead, the doctrine simply falls into the trap of assuming that competition necessarily must be harmed by misuse of a patent because each patent constitutes a separate inarket monopoly. ${ }^{190}$

186. See supra notes $84-94$ and accompanying text.

187. Merges, supra note 107, at 799-803.

188. Id. at 800 . Of course, if a thin market for the specific technology actually exists, one could have power in that thin market, and the antitrust test would be easier to satisfy. $C f$. Haddock, McChesney \& Spiegel, An Ordinary Economic Rationale for Extraordinary Legal Sanctions, 78 CALIF. L. Rev. 1, 21-24 (1990) (discussing the economics of damage awards in thick markets). Here, too, antitrust can address the issue correctly as long as the market is defined correctly.

189. See Merges, supra note 107, at 801 (agreeing that "there is evidence that market power does in some circumstances permit a licensor to 'extend' his monopoly").

Many scholars question whether tying arrangements ever harm competition, even when inarket power is present. Both R. BORK, supra note 111, at 372-75, and R. POSNER, supra note 73, at 17274, criticize the economic theory of leveraging (the prinuary rationale for banning tying arrangements in the patent context) itself. On the other hand, Kaplow, supra note 111, at 520-39, argues persuasively that tying arrangements with market power are anticompetitive. I am aware of no academic biterature suggesting that tie-ins without market power, the kind the patent misuse doctrine prohibits, are anticompetitive. $C f$. id. at 521-23 (Kaplow assumes that the tying arrangements he criticizes thrcaten market power).

190. In Senza-Gel Corp. v. Seiffhart, 803 F.2d 661 (Fed. Cir. 1986), the Federal Circuit required only that two different products exist, that their sale be tied, and that the tied product be a staple, in 
Finally, Merges discusses those licensing agreeinents that extend the patent royalty beyond seventeen years. ${ }^{191}$ Relying on Aronson v. Quick Point Pencil Co., ${ }^{192}$ lie argues that such agreements constitute patent misuse. There are two problems with this application of the patent misuse doctrine. First, agreeinents tliat extend royalty terms simply are not anticoinpetitive. A licensee will pay a fixed amount for a license, and the courts sliould not care whetlier tlie licensee pays that amount up front, in ten years, or in a liundred years. ${ }^{193}$ Second, if sucli an agreeinent does constitute patent misuse, the patent misuse remedy functions to bar all payinents under the licensing contract, rather than simply limiting the ternn to seventeen years. ${ }^{194}$ Such a remedy is clearly superoptimal. It is also unneeessary, since terms beyond seventeen years apparently can be voided under contract law principles. ${ }^{195}$

Moreover, even if the substantive prohibitions of the patent misuse doctrine are viable, tlie doctrine still imposes reinedies that bear no relationship to the severity of the misuse; in addition, the reinedies raise the prospect of dual sanctions in the event the misuse also constitutes an antitrust violation. Thus, Professor Merges' arguments do not justify retaining the doctrime. If it is assumed that the patent inisuse view of these practices is correct, a more appropriate solution would be to extend the scope of the antitrust laws to cover sucl practices.

Professor Nicoson makes one additional suggestion that is worth evaluating. He suggests that the patent misuse doctrine should withhold infringement relief where the patentee has used a tying arrangement to expand the scope of his patent and is now suing the infringer for

order to prove patent misuse. Id. at $664-65$; see id. at 668 (distinguishing patent misuse from antitrust claims for purposes of proving power and market definition). Thus, the court either abolished the market power test entirely im the patent misuse context or it assumed that a patent gives the patentee automatic market power.

Merges makes a similar argument in favor of patent misuse treatment of grant-back clauses. Merges, supra note 107, at 801-02. For purposes of his reasoming, grant-back clauses are the equivalent of tying arrangements and thus need not be treated separately here.

191. Merges, supra note 107 , at 802-03.

192. 440 U.S. $257,264-65$ (1979).

193. Some hicenses provide for metered royalties based on use. Even if one of these agreements extended to royalties beyond 17 years, the result would not be anticompetitive. After 17 years, the hicensee could simply begin to produce its own product (since it was no longer covered by a patent), and would not pay royalties to the patentee on the old patented product.

194. Consider the position of a heensce under a 20-year royalty contract. Knowing that the contract constitutes misuse, the hicensee will simply produce the hicensed product itself, and refuse to pay royalties to the patentee (simee the patentee's infringement action is barred by the patent misuse doctrine).

195. See Meehan v. PPG Indus., 802 F.2d 881, 886 (7th Cir. 1986) (when royalties payments extend unchanged beyond the life of a patent, the patent has been abused and the agreement is unlawful per se), cert. denied, 479 U.S. 1091 (1987); Boggild v. Kenner Prods., 776 F.2d 1315, 1320. 21 (6th Cir. 1985) (where pre-expiration and post-expiration royalties are same, agreement is per se unlawful), cert. denied, 477 U.S. 908 (1986). 
encroaching on the expanded area (i.e., that not originally covered in the patent grant). ${ }^{196}$ While a patentee certainly should be denied relief in such a case, the patent misuse doctrine is not necessary to accomplish sucli a result. Because the patentee's claim for protection is outside the grounds of the original patent grant (by postulate), the courts will not find infringement as a matter of substantive patent law. ${ }^{197}$

In short, there is no reason to retain specific parts of the patent misuse doctrine, and very good reason to abolish the entire defense. As a corollary to the rejection of the patent misuse doctrine itself, we should also reject the legislation designed to reform it, discussed above in Part V. In large part, this legislation misses the true failures of the patent misuse doctrime.

Yet there may well be areas where the antitrust laws do not deter anticompetitive conduct sufficiently. If the patent misuse defense is abolished, the responsibility for protection against sucli anticompetitive acts will devolve upon the antitrust laws. While a detailed discussion of the virtues of various provisions of the antitrust laws is beyond the scope of this Comment, I suggest as a general matter that the problem should be solved there. ${ }^{198}$ For the reasons discussed in Part IV, enforcing norina-

196. Nicoson, supra note 183 , at 109.

197. See, e.g., McGill, Inc. v. John Zink Co., 736 F.2d 666, 672-76 (Fed. Cir.) (for purposes of infringement suit, scope of patent is determined by looking at the nature of the claims made when the patent was filed), cert. denied, 469 U.S. 1037 (1984).

198. In the interest of fairness, I will make a number of substantive suggestions for such changes in the antitrust laws. First, the courts should not shy away from finding a patentee guilty of monopolization. Concomitant with a recognition that a patent does not always confer market power should be a willingness to punish patentees who attempt to acquire such power through anticompetitive means. Second, United States v. General Electric Co., 272 U.S. 476 (1926), should be overruled, and the antitrust laws should apply with full force to patent-based cartels and pooling arrangements. Third, the courts should equate the requirements for leveraging in patent and nonpatent cases. All these changes would allow cquivalent treatment of patentees and other antitrust defendants.

Finally, courts should be willing, in appropriate cases, to use compulsory licensing as an antitrust remedy. The problems with compulsory licensing are discussed at supra notes 60-64 and aecompanying text. There are ways around the "reasonable rate"/regulation dilemma, however. For example, a compulsory licensing system in which the court requires a patentee to license his patent to the highest bidder in an auction will, under competitive conditions, produce the equivalent of market price.

As described, this bid system will produce only one licensee (the highest bidder). However, the systein could easily be modified (if one is unconcerned with price discrimination) to license as many companies as desired at the price each bids. As an alternative, the system could select a set number of hicensees $(n)$ in advance, and rcquire eacli to pay the royalty bid by the $n$th bidder. See McAfee \& McMillan, Auctions and Bidding, 25 J. EcoN. LiT. 699, 702-03 (1987) (describing such "Vickrey auctions"); Rothkopf, Teisberg \& Kahn, Why Are Vickrey Auctions Rare?, Lawrence Berkeley Laboratory Working Paper No. LBL-24227 (Dec. 16, 1987) (considering effeets of Vickrey auctions on bid taker cheating and strategic control of information). Sucl a system is gaining imcreasing acceptance in the utility indnstry. See, e.g., Rozek, Competitive Bidding in Electricity Markets: $A$ Survey, 10 ENERGY J. 117 (1989) (many states and federal government are considering such auctions). Nonetheless, becanse a patentee theoretically receives a monopoly price on his patent 
tive policies through the antitrust laws is superior to taking equivalent actions through the patent misuse doctrine.

Abolition of the patent misuse doctrine will go a long way toward restoring economic rationality to a confused and largely illogical area of the law. Abolition alone is not enougl, of course. Nonetlieless, it is an miportant first step on the road towards optimizing sanctions against patentees who misuse their patents. 